Review

\title{
Recent Progress in Metal Borohydrides for Hydrogen Storage
}

\author{
Hai-Wen Li ${ }^{1, *}$, Yigang Yan ${ }^{1}$, Shin-ichi Orimo ${ }^{1}$, Andreas Züttel ${ }^{2}$ and Craig M. Jensen ${ }^{3}$ \\ 1 Institute for Materials Research (IMR), Tohoku University, Sendai 980-8577, Japan; \\ E-Mails: yg-yan@imr.tohoku.ac.jp (Y.Y.); orimo@imr.tohoku.ac.jp (S.O.) \\ 2 Department of the Environment, Energy and Mobility (EMPA), Abt. 138 "Hydrogen \& Energy", \\ Überlandstrasse 129, 8600 Dübendorf, Switzerland; E-Mail: Andreas.Zuettel@empa.ch \\ 3 Department of Chemistry, University of Hawaii, Honolulu, HI 96822, USA; \\ E-Mail: jensen@hawaii.edu \\ * Author to whom correspondence should be addressed; E-Mail: lihw@imr.tohoku.ac.jp; \\ Tel.: +81-22-215-2093; Fax: +81-22-215-2091.
}

Received: 23 November 2010; in revised form: 22 December 2010 / Accepted: 17 January 2011 / Published: 24 January 2011

\begin{abstract}
The prerequisite for widespread use of hydrogen as an energy carrier is the development of new materials that can safely store it at high gravimetric and volumetric densities. Metal borohydrides $M\left(\mathrm{BH}_{4}\right)_{n}$ ( $n$ is the valence of metal $M$ ), in particular, have high hydrogen density, and are therefore regarded as one such potential hydrogen storage material. For fuel cell vehicles, the goal for on-board storage systems is to achieve reversible store at high density but moderate temperature and hydrogen pressure. To this end, a large amount of effort has been devoted to improvements in their thermodynamic and kinetic aspects. This review provides an overview of recent research activity on various $M\left(\mathrm{BH}_{4}\right)_{n}$, with a focus on the fundamental dehydrogenation and rehydrogenation properties and on providing guidance for material design in terms of tailoring thermodynamics and promoting kinetics for hydrogen storage.
\end{abstract}

Keywords: hydrogen; hydride; borohydride; hydrogen storage

\section{Introduction}

Development of advanced hydrogen storage materials for onboard hydrogen storage systems is regarded as a key prerequisite for widespread adoption of fuel cell vehicles. For commercial vehicle 
applications, hydrogen storage materials must possess all the following capabilities: high gravimetric hydrogen density, adequate hydrogenation-dehydrogenation temperature/rate, cycling stability, and low cost [1].

Metal borohydrides $M\left(\mathrm{BH}_{4}\right)_{n}$ ( $n$ indicates the valence of $M$ ) have high gravimetric hydrogen densities and thus have attracted great interest for use in hydrogen storage [2]. The gravimetric hydrogen densities and physical properties of various $M\left(\mathrm{BH}_{4}\right)_{n}$ [3] are shown in Figure 1 and Table 1, respectively.

Figure 1. Elements $M$ formed $M\left(\mathrm{BH}_{4}\right)_{\mathrm{n}}$, their gravimetric hydorgne densities in the unit of mass\%. Asterisks indicate compounds stabilizaed at room temperature by coordiantion with ligands. Brackets indicate compounds reported to be unstable at room temperature but may be isolated at low temperature [3]. Reproduced with permission from reference 3.

\begin{tabular}{|c|c|c|c|c|c|c|c|c|c|c|c|c|c|c|c|}
\hline 1 & 2 & & & & & & & & & & & & & \multirow[b]{2}{*}{13} & \multirow[b]{2}{*}{14} \\
\hline $\begin{array}{c}\mathrm{Li} \\
18.5\end{array}$ & $\begin{array}{c}\mathrm{Be} \\
20.8\end{array}$ & & & & & & & & & & & & & & \\
\hline $\begin{array}{c}\mathrm{Na} \\
10.7\end{array}$ & $\begin{array}{c}\mathrm{Mg} \\
14.9\end{array}$ & 3 & & 4 & 5 & 6 & 7 & 8 & 9 & 10 & 1 & & 12 & $\begin{array}{l}{[\mathrm{Al}]} \\
16.9 \\
\end{array}$ & \\
\hline $\begin{array}{c}\mathrm{K} \\
7.5\end{array}$ & $\begin{array}{c}\mathrm{Ca} \\
11.6 \\
\end{array}$ & $\begin{array}{c}\mathrm{Sc} \\
13.5 \\
\end{array}$ & & \begin{tabular}{l|l}
$\mathrm{Ti}$ & \\
13.1 & \\
15.0 & 1 \\
\end{tabular} & $\begin{array}{c}\text { V } \\
12.7\end{array}$ & $\begin{array}{c}\mathrm{Cr} \\
9.9 \\
\end{array}$ & $\begin{array}{c}{[\mathrm{Mn}]} \\
9.5\end{array}$ & $\begin{array}{c}{[\mathrm{Fe}]} \\
9.4\end{array}$ & $\begin{array}{c}{[\mathrm{Co}]} \\
9.1 \\
\end{array}$ & $\begin{array}{c}{[\mathrm{Ni}]} \\
9.1\end{array}$ & $\begin{array}{r}{[\mathrm{Cl}} \\
5 .\end{array}$ & & $\begin{array}{l}\mathrm{Zn} \\
4.4 \\
\end{array}$ & $\begin{array}{l}{[\mathrm{Ga}]} \\
10.6\end{array}$ & $\begin{array}{c}\mathrm{Ge} \\
12.2 \\
\end{array}$ \\
\hline $\begin{array}{l}\mathrm{Rb} \\
4.0\end{array}$ & $\begin{array}{l}\mathrm{Sr} \\
6.9 \\
\end{array}$ & $\begin{array}{c}\mathrm{Y} \\
9.1\end{array}$ & & \begin{tabular}{l|l}
$\mathrm{Zr}$ & $\mathrm{I}$ \\
0.7 & 8 \\
\end{tabular} & $\begin{array}{l}\mathrm{Nb} \\
8.8\end{array}$ & & & & & & $\begin{array}{l}{\left[\mathrm{A}_{\xi}\right.} \\
3 .\end{array}$ & & \begin{tabular}{|c|}
{$[\mathrm{Cd}]$} \\
2.9
\end{tabular} & $\begin{array}{c}{[\text { In] }} \\
7.6\end{array}$ & $\begin{array}{c}{[\mathrm{Sn}]} \\
9.1\end{array}$ \\
\hline $\begin{array}{l}\mathrm{Cs} \\
2.7\end{array}$ & $\begin{array}{l}\mathrm{Ba} \\
4.8\end{array}$ & Ln & & $\begin{array}{l}\mathrm{Hf} \\
6.8\end{array}$ & & & & & & & $\begin{array}{l}{[\mathrm{A}} \\
1 .\end{array}$ & & $\begin{array}{l}\mathrm{Hg} \\
1.8\end{array}$ & $\begin{array}{r}\mathrm{T} 1 \\
4.9\end{array}$ & \\
\hline & & $\mathrm{Ac}$ & & & & & & & & & & & & & \\
\hline $\mathrm{Ln}$ & $\begin{array}{l}\mathrm{La} \\
6.6 \\
\end{array}$ & $\begin{array}{l}\mathrm{Ce} \\
6.6 \\
\end{array}$ & & $\begin{array}{l}\mathrm{Nd} \\
6.4 \\
\end{array}$ & & $\begin{array}{l}\mathrm{Sm} \\
6.2 \\
\end{array}$ & $\begin{array}{l}\mathrm{Eu} \\
6.2 \\
\end{array}$ & $\begin{array}{l}\mathrm{Gd} \\
6.0 \\
\end{array}$ & $\begin{array}{l}\mathrm{Tb} \\
5.9 \\
\end{array}$ & $\begin{array}{l}\text { Dy } \\
5.8 \\
\end{array}$ & $\begin{array}{l}\text { Ho } \\
5.8 \\
\end{array}$ & $\begin{array}{l}\mathrm{Er} \\
5.7 \\
\end{array}$ & $\begin{array}{l}\mathrm{Tm} \\
5.7 \\
\end{array}$ & $\begin{array}{l}\mathrm{Yb} \\
5.6 \\
\end{array}$ & $\begin{array}{l}\mathrm{Lu} \\
5.5 \\
\end{array}$ \\
\hline Ac & & $\begin{array}{l}\text { Th } \\
5.5\end{array}$ & $\begin{array}{l}\mathrm{Pa} \\
5.6\end{array}$ & \begin{tabular}{|c|}
$\mathrm{U}$ \\
III 4.3 \\
IV 5.4
\end{tabular} & $\begin{array}{l}\mathrm{Np} \\
5.4\end{array}$ & $\begin{array}{l}\mathrm{Pu} \\
5.4\end{array}$ & & & & & & & & & \\
\hline
\end{tabular}

Table 1. Density of $M\left(\mathrm{BH}_{4}\right)_{n}$ and hydrogen density in $M\left(\mathrm{BH}_{4}\right)_{n}$ [3]. Reproduced with permission from reference 3 .

\begin{tabular}{cccccc}
\hline $\boldsymbol{M}\left(\mathbf{B H}_{4}\right)_{\mathbf{n}}$ & CAS No. & $\begin{array}{c}\text { Density } \\
(\mathbf{g} / \mathbf{m o l})\end{array}$ & $\begin{array}{c}\text { Density } \\
\left(\mathbf{g} / \mathbf{c m}^{\mathbf{3}}\right)\end{array}$ & $\begin{array}{c}\text { Hydrogen } \\
\text { Density } \\
\text { (mass\%) }\end{array}$ & $\begin{array}{c}\text { Hydrogen } \\
\text { Density } \\
\left(\mathbf{k g} / \mathbf{m}^{\mathbf{3}}\right)\end{array}$ \\
\hline $\mathrm{LiBH}_{4}$ & $16949-15-8$ & 21.78 & 0.66 & 18.5 & 122.1 \\
$\mathrm{NaBH}_{4}$ & $16940-66-2$ & 37.83 & 1.07 & 10.7 & 114.5 \\
$\mathrm{KBH}_{4}$ & $13762-51-1$ & 53.94 & 1.17 & 7.5 & 87.8 \\
$\mathrm{RbBH}_{4}$ & $20346-99-0$ & 100.31 & 1.92 & 4.0 & 76.8 \\
$\mathrm{CsBH}_{4}$ & - & 147.75 & 2.42 & 2.7 & 65.3 \\
$\mathrm{Be}\left(\mathrm{BH}_{4}\right)_{2}$ & $17440-85-6$ & 38.70 & 0.702 & 20.8 & 146.0 \\
$\mathrm{Mg}\left(\mathrm{BH}_{4}\right)_{2}$ & $16903-37-0$ & 53.99 & 0.989 & 14.9 & 147.4 \\
$\mathrm{Ca}\left(\mathrm{BH}_{4}\right)_{2}$ & $17068-95-0$ & 69.76 & $(1.07)$ & 11.6 & $(124.1)$ \\
$\mathrm{Mn}\left(\mathrm{BH}_{4}\right)_{2}$ & - & 84.62 & $(1.24)$ & 9.5 & $(117.8)$ \\
$\mathrm{Al}\left(\mathrm{BH}_{4}\right)_{3}$ & $16962-07-5$ & 71.51 & 0.79 & 16.9 & 133.5 \\
$\mathrm{Zr}\left(\mathrm{BH}_{4}\right)_{4}$ & $12370-59-1$ & 150.6 & 1.179 & 10.7 & 126.2 \\
$\mathrm{Hf}\left(\mathrm{BH}_{4}\right)_{4}$ & $53608-70-1$ & 237.6 & 1.65 & 6.8 & 112.2 \\
\hline
\end{tabular}

Densities in brackets shows the value calculated from the crystal structure. 
First-principles calculations of the electronic structures of $M\left(\mathrm{BH}_{4}\right)_{n}$ show that they are nonmetallic and have relatively large energy gaps of 1.8-6.8 eV. A boron atom forms covalent bonds with four surrounding $\mathrm{H}$ atoms to form $\left[\mathrm{BH}_{4}\right]^{-}$anions, the charge of which is compensated by metal cations $M^{n+}$. The electronic structures indicate that charge transfer from the metal cations $M^{n+}$ to the $\left[\mathrm{BH}_{4}\right]^{-}$anions is a key feature determining the thermodynamic stability of $M\left(\mathrm{BH}_{4}\right)_{n}$ [4-8].

Some $M\left(\mathrm{BH}_{4}\right)_{n}$ have been used as "one-way" hydrogen sources that release the hydrogen on contact with water (via hydrolysis) [9-11]. Because the hydrolysis reaction is highly irreversible, such materials are certainly not candidates for reversible hydrogen storage. In this review, we focus on the recent progress in the dehydrogenation and rehydrogenation reactions of $M\left(\mathrm{BH}_{4}\right)_{n}$ at controlled temperature and hydrogen pressure. Some several excellent reviews on $M\left(\mathrm{BH}_{4}\right)_{n}$ are also available $[2,12-18]$.

\section{Fundamentals of Hydrogen Storage Properties}

The study of $M\left(\mathrm{BH}_{4}\right)_{n}$ as a candidate hydrogen storage material started with $\mathrm{LiBH}_{4}$ [19]. It releases 13.8 mass $\%$ of hydrogen by decomposition into $\mathrm{LiH}$ and $\mathrm{B}$ [19-25]. The dehydrogenation process at a low heating rate $(0.5 \mathrm{~K} / \mathrm{min})$ exhibits three distinct desorption peaks, which indicates that it involves several intermediate steps [25]. This was recently explained by the formation of $\mathrm{Li}_{2} \mathrm{~B}_{12} \mathrm{H}_{12}$ as an intermediate compound, evidenced by Raman and solid-state CP/MAS NMR analyses, as well as theoretical prediction [26-29]. $\mathrm{Li}_{2} \mathrm{~B}_{12} \mathrm{H}_{12}$ has a cubic crystal structure with Pa3 symmetry [30]. A mechanistic explanation of the formation of $\mathrm{Li}_{2} \mathrm{~B}_{12} \mathrm{H}_{12}$ indicates that the diborane or higher borane species formed during the decomposition of $\mathrm{LiBH}_{4}$ would react with the remaining $\mathrm{LiBH}_{4}$ to afford $\mathrm{Li}_{2} \mathrm{~B}_{12} \mathrm{H}_{12}$ and possibly even $\mathrm{Li}_{2} \mathrm{~B}_{10} \mathrm{H}_{10}$ [31]. To understand the mechanism of dehydrogenation better, intensive investigations on the dynamics have been performed, including on the rotational and vibration motions of $\mathrm{BH}_{4}$ tetrahedra; the atomic motions of $\mathrm{H}, \mathrm{Li}$, and $\mathrm{B} ; \mathrm{H}-\mathrm{D}$ exchange in $\mathrm{BH}_{4}$ units, etc. [32-50]. The enthalpy $\Delta H$ and entropy $\Delta S$ of dehydrogenation were found to be $74 \mathrm{~kJ} \mathrm{~mol}^{-1} \mathrm{H}_{2}$ and $115 \mathrm{~J} \mathrm{~K}^{-1} \mathrm{~mol}^{-1} \mathrm{H}_{2}$, respectively, based on the pressure-concentration-temperature (PCT) isotherm measurement [51].

Dehydrogenation of $\mathrm{LiBH}_{4}$ is reversible, because the end products lithium hydride $(\mathrm{LiH})$ and boron absorb hydrogen at $873 \mathrm{~K}$ in a hydrogen pressure of $35 \mathrm{MPa}$ for $12 \mathrm{~h}$ [23] or at $1000 \mathrm{~K}$ under a hydrogen pressure of $15 \mathrm{MPa}$ for over $10 \mathrm{~h} \mathrm{[25]} \mathrm{to} \mathrm{form} \mathrm{LiBH}_{4}$. The high rehydrogenation temperature of above $873 \mathrm{~K}$ might be due to the sluggish kinetics of rehydrogenation, which requires recombination of the dehydrogenated $\mathrm{LiH}$ and $\mathrm{B}$, that is, breaking of the rigid boron lattice, and the subsequent diffusion of $\mathrm{Li}$ and $\mathrm{B}$ atoms toward each other would be mainly responsible for the sluggish kinetics. The sluggish kinetics can be enhanced by preparing a homogenous dispersion of $\mathrm{Li}$ and $\mathrm{B}$ atoms on an atomic level. For example, forming a binary $\mathrm{LiB}_{x}$ compound (e.g., $\mathrm{Li}_{7} \mathrm{~B}_{6}, \mathrm{LiB}_{3}$, and $\mathrm{LiB}$, etc.) has been proved to significantly improve the reaction kinetics of $\mathrm{LiBH}_{4}$ formation over that of the $\mathrm{Li} / \mathrm{B}$ mixture [51-53]. In addition, the formation of $\mathrm{LiBH}_{4}$ might be related to diborane $\mathrm{B}_{2} \mathrm{H}_{6}[53-55]$.

$\mathrm{Mg}\left(\mathrm{BH}_{4}\right)_{2}$ releases approximately 14.9 mass\% of hydrogen when heated up to $870 \mathrm{~K}$ [56-66]. The dehydrogenation process is found to also proceed through multiple steps together with the formation of intermediate compounds $[62,63,65]$, as summarized in Figure 2. Thus far, one of the intermediate 
compounds has been theoretically predicted and experimentally confirmed as being $\mathrm{MgB}_{12} \mathrm{H}_{12}$ $[28,29,62,65-70]$ similar to that in the case of $\mathrm{LiBH}_{4}$ [26]. The lowest energy configuration of $\mathrm{MgB}_{12} \mathrm{H}_{12}$ was predicted as being monoclinic in the space group $C 2 / m$ (No. 12) [29]. Anhydrous $\mathrm{MgB}_{12} \mathrm{H}_{12}$ cannot be obtained from simple thermal decomposition of $\mathrm{Mg}\left(\mathrm{H}_{2} \mathrm{O}\right)_{6} \mathrm{~B}_{12} \mathrm{H}_{12} \cdot 6 \mathrm{H}_{2} \mathrm{O}$ [71]. The apparent enthalpy and entropy for the conversion of $\mathrm{Mg}\left(\mathrm{BH}_{4}\right)_{2}$ to $\mathrm{MgH}_{2}$ were estimated from PCT measurement to be $39 \mathrm{~kJ} \mathrm{~mol}^{-1} \mathrm{H}_{2}$ and $91 \mathrm{~J} \mathrm{~K}^{-1} \mathrm{~mol}^{-1} \mathrm{H}_{2}$ [56], respectively. In a later work, different values were reported: $\Delta H=57 \mathrm{~kJ} \mathrm{~mol}^{-1} \mathrm{H}_{2}$ and $\Delta S=128 \mathrm{~J} \mathrm{~K}^{-1} \mathrm{~mol}^{-1} \mathrm{H}_{2}$ [62]. These differences might originate from differences in the measurement conditions. For example, a shorter equivalent judgment time will lead to a higher plateau due to the sluggish kinetics.

Figure 2. The dehydrogenation processes of $\mathrm{Mg}\left(\mathrm{BH}_{4}\right)_{2}$ based on the respective reports. Question mark indicates the possibility of the formation of an intermediate compound during the dehydrogenation.

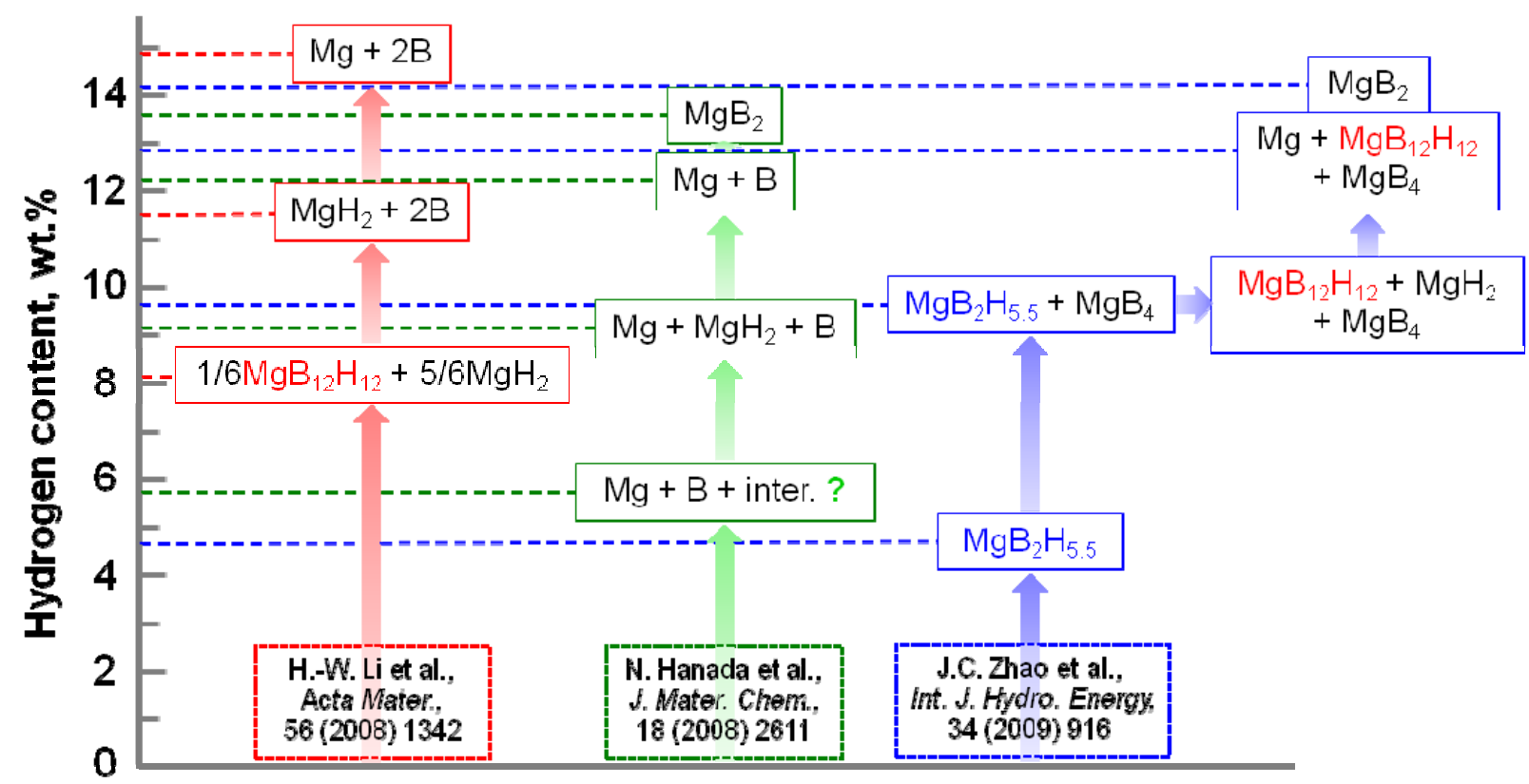

$\mathrm{Mg}\left(\mathrm{BH}_{4}\right)_{2}$

Rehydrogenation of $\mathrm{Mg}\left(\mathrm{BH}_{4}\right)_{2}$ occurs at $543 \mathrm{~K}$ in a hydrogen pressure of $40 \mathrm{MPa}$ for $48 \mathrm{~h}$. Approximately 6.1 mass $\%$ of hydrogen is rehydrogenated through the formation of $\mathrm{MgB}_{12} \mathrm{H}_{12}[62,66]$. The formation of $\mathrm{MgB}_{12} \mathrm{H}_{12}$, rather than $\mathrm{Mg}\left(\mathrm{BH}_{4}\right)_{2}$, after rehydrogenation may be explained from the viewpoint of the crystal (cluster) structure. The formation of $\mathrm{Mg}\left(\mathrm{BH}_{4}\right)_{2}$ is more thermodynamically favorable than that of $\mathrm{MgB}_{12} \mathrm{H}_{12}$ from the dehydrogenated products $\left(\mathrm{MgH}_{2}\right.$ and boron) at $573 \mathrm{~K}$. However, for the formation of $\mathrm{Mg}\left(\mathrm{BH}_{4}\right)_{2}$, the $\mathrm{B}-\mathrm{B}$ bonds in the icosahedral cluster of $\mathrm{B}$ should be broken and the $\mathrm{B}$ atoms should spatially migrate to form $\left[\mathrm{BH}_{4}\right]^{-}$. The barrier against breaking of the $\mathrm{B}-\mathrm{B}$ bonds and migration of the $\mathrm{B}$ atoms is probably too high to overcome under the present rehydrogenation conditions [66]. However, it is almost the same boron icosahedral clusters in between $\mathrm{B}$ and $\mathrm{MgB}_{12} \mathrm{H}_{12}$ that facilitate the formation of $\left[\mathrm{B}_{12} \mathrm{H}_{12}\right]^{2-}$. In other words, the formation of $\mathrm{Mg}\left(\mathrm{BH}_{4}\right)_{2}$ requires higher temperature and pressure to overcome the aforementioned barriers. This was proven in a recent study: partial formation of $\mathrm{Mg}\left(\mathrm{BH}_{4}\right)_{2}$ was confirmed in rehydrogenation experiments carried out at $663 \mathrm{~K}$ in a hydrogen pressure of $90 \mathrm{MPa}$ for 3 days [72]. In addition, $\mathrm{Mg}\left(\mathrm{BH}_{4}\right)_{2}$ can be prepared 
by hydrogenation of $\mathrm{MgB}_{2}$ at $673 \mathrm{~K}$ under a hydrogen pressure of $90 \mathrm{MPa}$ for a few days [73]. This hydrogenation reaction can be greatly promoted by using nanostructures with grain boundary defects introduced by mechanical milling [73-75]. Recently, $\mathrm{Mg}\left(\mathrm{BH}_{4}\right)_{2}$ was found to be formed by hydrogenation of $\mathrm{Mg}\left(\mathrm{B}_{3} \mathrm{H}_{8}\right)_{2}$ at $523 \mathrm{~K}$ under a hydrogen pressure of $12 \mathrm{MPa}$ [76].

$\mathrm{Ca}\left(\mathrm{BH}_{4}\right)_{2}$ was theoretically predicted to release 9.6 mass $\%$ of hydrogen according to the following reaction [77]:

$$
\mathrm{Ca}\left(\mathrm{BH}_{4}\right)_{2}=2 / 3 \mathrm{CaH}_{2}+1 / 3 \mathrm{CaB}_{6}+10 / 3 \mathrm{H}_{2}
$$

Experimentally, approximately 9.0 mass\% of hydrogen was released when $\mathrm{Ca}\left(\mathrm{BH}_{4}\right)_{2}$ was heated to $800 \mathrm{~K}$ [78-80]. This value shows good agreement with that predicted by Equation 1. The presence of two endothermic peaks corresponding to dehydrogenation suggests the formation of intermediate compounds, which is confirmed by the powder X-ray diffraction (XRD) analyses of the dehydrogenated products that were heated to approximately $663 \mathrm{~K}$ [78] and after the plateau in the PCT profile measured at $593 \mathrm{~K}$ [79]. The intermediate compound is suggested to be a $\mathrm{CaB}_{2} \mathrm{H}_{x}$ compound having a $\mathrm{HgCl}_{2}$-type structure with Pnma symmetry according to the high-resolution synchrotron radiation powder XRD measurement [81]. By contrast, the proposed $\mathrm{CaB}_{2} \mathrm{H}_{x}$ was predicted to be both structurally unstable and too high in energy to be a dehydrogenation intermediate based on the plane wave density functional theory calculations [82]. The formation of $\mathrm{CaB}_{12} \mathrm{H}_{12}$ as an intermediate compound is suggested by the experiment and first-principle calculations $[29,69,70,83]$. A pure $\mathrm{CaB}_{12} \mathrm{H}_{12}$ compound has been synthesized and the crystal structure has been determined to be monoclinic with $C 2 / C$ symmetry [84]. Identification of the intermediate compound is expected to increase our understanding of the dehydrogenation process of $\mathrm{Ca}\left(\mathrm{BH}_{4}\right)_{2}$. The enthalpy and entropy change for the first step of dehydrogenation are estimated to be $\Delta H=87 \mathrm{~kJ} \mathrm{~mol}^{-1} \mathrm{H}_{2}$ and $\Delta S=158 \mathrm{~J} \mathrm{~K}^{-1} \mathrm{~mol}^{-1} \mathrm{H}_{2}$ [80], respectively.

Regarding the rehydrogenation properties of pure $\mathrm{Ca}\left(\mathrm{BH}_{4}\right)_{2}$, no tangible data are available. $\mathrm{Ca}\left(\mathrm{BH}_{4}\right)_{2}$ has been predicted theoretically to have limited viability as a reversible storage material for on-board storage due to the formation of a stable intermediate compound of $\mathrm{CaB}_{12} \mathrm{H}_{12}$ [83]. It was found that the ball-milled mixtures of $\mathrm{CaB}_{12} \mathrm{H}_{12}$ and $\mathrm{CaH}_{2}$ do not produce $\mathrm{Ca}\left(\mathrm{BH}_{4}\right)_{2}$ during the rehydrogenation test at $670 \mathrm{~K}$ in a hydrogen pressure of $100 \mathrm{MPa}$ [84]. With additives, approximately $57 \%$ of the $\mathrm{Ca}\left(\mathrm{BH}_{4}\right)_{2}$ is obtained by rehydrogenation at $623 \mathrm{~K}$ in a hydrogen pressure of $10 \mathrm{MPa}$ [85-87].

$\mathrm{Y}\left(\mathrm{BH}_{4}\right)_{3}$ releases approximately 7.8 mass $\%$ of hydrogen when heated to $773 \mathrm{~K}$ [88-93]. This value is almost equal to the theoretical dehydrogenation content ( 7.5 mass $\%)$ according to the assumed reaction:

$$
\mathrm{Y}\left(\mathrm{BH}_{4}\right)_{3}=\mathrm{YH}_{2}+3 \mathrm{~B}+5 \mathrm{H}_{2}
$$

The whole reaction process of $\mathrm{Y}\left(\mathrm{BH}_{4}\right)_{3}$ on heating to $773 \mathrm{~K}$ is summarized as follows: (1) phase transformation, (2) melting, (3) decomposition of $\left.\mathrm{Y}_{(\mathrm{BH}}\right)_{3}$ into an intermediate compound and $\mathrm{YH}_{3}$, (4) decomposition of the intermediate compound, and (5) decomposition of $\mathrm{YH}_{3}$ into $\mathrm{YH}_{2}$ [89]. Approximately 1.1-1.3 mass\% of hydrogen was rehydrogenated at $573 \mathrm{~K}$ in a hydrogen pressure of 35 $\mathrm{MPa}$ for $24 \mathrm{~h}$ [89]. Similar to that of $\left.\mathrm{Y}_{(\mathrm{BH}}\right)_{3}$, a multistep dehydrogenation process were also confirmed in $\mathrm{Ce}\left(\mathrm{BH}_{4}\right)_{3}$ [94]. In addition, there are several other $M\left(\mathrm{BH}_{4}\right)_{n}$ (e.g., $\mathrm{M}=\mathrm{Zn}, \mathrm{Al}, \mathrm{Ti}, \mathrm{Mn}$ and 
Zr) [95-103]. Most of these were found to be irreversible due to their low melting temperatures and the release of diborane with hydrogen.

\section{Improvement of Hydrogen Storage Properties}

\subsection{Tailoring Thermodynamics}

In principle, the Gibbs free energy for a certain reaction determines the reaction temperature. Taking into account that the entropy change $\Delta S$ mainly comes from the gaseous hydrogen (i.e., a constant $\mathrm{S}_{\mathrm{H} 2}^{0}=130 \mathrm{~J} \cdot \mathrm{K}^{-1} \mathrm{~mol}^{-1} \mathrm{H}_{2}$ ), enthalpy change $\Delta H$ becomes the specific indicator to evaluate thermodynamic stability. For metal borohydrides, $\Delta H$ is calculated from the difference in the heat of formation between the product and starting materials. Therefore, two main approaches to tailor the thermodynamic stabilities from both sides - the starting materials and products - are expected: (a) destabilization of $M\left(\mathrm{BH}_{4}\right)_{n}$ and (b) stabilization of dehydrogenation products, as shown in Figure 3.

Figure 3. Schematic illustration of two main approaches to tailor the thermodynamic stabilities of metal borohydrides $M\left(\mathrm{BH}_{4}\right)_{n}$ : (a) destabilization of $M\left(\mathrm{BH}_{4}\right)_{n}$ and (b) stabilization of dehydrogenation products.

\section{Products of dehydriding reactions}

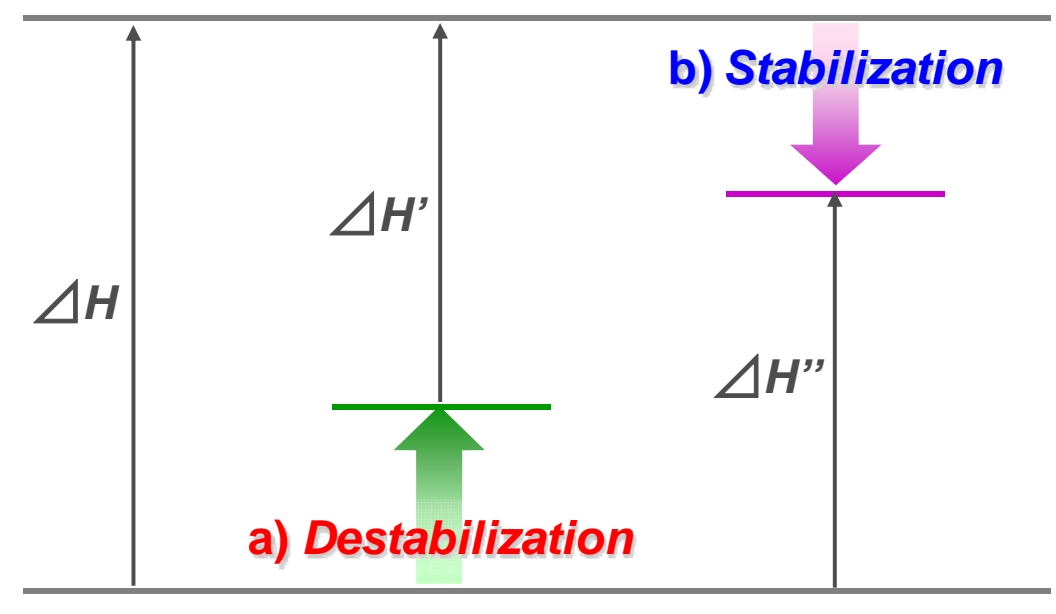

\section{Metal borohydrides, $M\left(\mathrm{BH}_{4}\right)_{n}$}

One approach to reducing the enthalpy change $\Delta H_{\text {deh }}$ is the destabilization of $M\left(\mathrm{BH}_{4}\right)_{n}$, as illustrated in Figure 3. The thermodynamic stabilities for the series of metal borohydrides $M\left(\mathrm{BH}_{4}\right)_{n}(M=\mathrm{Li}, \mathrm{Na}$, $\mathrm{K}, \mathrm{Mg}, \mathrm{Ca}, \mathrm{Sc}, \mathrm{Zr}, \mathrm{Hf}, \mathrm{Cu}, \mathrm{Zn}$, and $\mathrm{Al} ; n=1-4$ ) have been systematically investigated using first-principles calculations [104]. A good correlation between the predicted heat of formation $\Delta H_{\text {form }}$ of $M\left(\mathrm{BH}_{4}\right)_{n}$ and the Pauling electronegativity $\chi_{\mathrm{P}}$ of $M$ is found, which suggests that the $\chi_{\mathrm{P}}$ is a useful indicator to estimate the thermodynamic stability of $M\left(\mathrm{BH}_{4}\right)_{n}$.

The enthalpy change $\Delta H_{\text {deh }}$ of the dehydrogenation of $M\left(\mathrm{BH}_{4}\right)_{n}$ correlates not only with the stability of $M\left(\mathrm{BH}_{4}\right)_{n}$, but also with the stability of the products. The dehydrogenation reactions were assumed as the following equation:

$$
M\left(\mathrm{BH}_{4}\right)_{n}=M \mathrm{H}_{m}+n \mathrm{~B}+(4 n-m) / 2 \mathrm{H}_{2}
$$


In the case of no $M \mathrm{H}_{m}$ formation, direct decomposition into elements was assumed. Then, the $\Delta H_{\text {deh }}$ of the dehydrogenation was estimated using the reported values of $\Delta H_{\text {prod }}$ and predicted $\Delta H_{\text {form}}$ :

$$
\Delta H_{\text {deh }}=\Delta H_{\text {prod }}-\Delta H_{\text {form }}
$$

A good correlation between $\Delta H_{\text {deh }}$ and $\chi_{\mathrm{P}}$ was also obtained according to the theoretical prediction. Furthermore, it is expected that $M\left(\mathrm{BH}_{4}\right)_{n}$ with $\chi_{\mathrm{P}} \geq 1.5$ are thermodynamically unstable [3]. The dehydrogenation properties were experimentally investigated using thermal desorption analysis during the heating process for milling samples [104-106]. A good correlation between $T_{\mathrm{d}}$ (defined as the temperature of the first peak) and $\chi_{\mathrm{P}}$ was confirmed experimentally, and was similar to that predicted by the first-principles calculations. Therefore, both the theoretical prediction and the experimental results consistently indicate that $T_{\mathrm{d}}$ can be roughly estimated by considering $\chi_{\mathrm{P}}$ as an indicator.

Inspired by this finding, an approach of producing multi cation borohydrides $M M^{\prime}\left(\mathrm{BH}_{4}\right)_{n}$, in which $M$ and $M^{\prime}$ have different electronegativities has been proposed to precisely tailor the thermodynamic stability [107]. Several typical samples has been synthesized, including $\operatorname{LiZr}\left(\mathrm{BH}_{4}\right)_{5}, \mathrm{Li}_{2} \mathrm{Zr}\left(\mathrm{BH}_{4}\right)_{6}$, $\mathrm{LiK}\left(\mathrm{BH}_{4}\right)_{2}, \mathrm{LiSc}\left(\mathrm{BH}_{4}\right)_{4}, \mathrm{KSc}\left(\mathrm{BH}_{4}\right)_{4}$, and so on [107-117]. Note that some samples were reported to form a large $\left[M^{\prime}\left(\mathrm{BH}_{4}\right)_{n}\right]^{m-}$ complex anion units such as $\left[\mathrm{Sc}\left(\mathrm{BH}_{4}\right)_{4}\right]^{-}[109,117]$, rather than the bimetallic borohydrides. Most of the $M M^{\prime}\left(\mathrm{BH}_{4}\right)_{n}$ exhibit moderate thermodynamic stabilities between $M\left(\mathrm{BH}_{4}\right)_{n}$ and $M^{\prime}\left(\mathrm{BH}_{4}\right)_{n}$. The appropriate combination of cations might be an effective method for adjusting the thermodynamic stability of metal borohydrides, similar to the conventional "alloying" method for hydrogen storage alloys. The detailed dehydrogenation-rehydrogenation properties of the recently synthesized $M M^{\prime}\left(\mathrm{BH}_{4}\right)_{n}$ are given in Table 2 .

Table 2. Hydrogen storage properties of bimetallic borohydrides, $M M^{\prime}\left(\mathrm{BH}_{4}\right)_{n}$.

\begin{tabular}{|c|c|c|c|c|c|c|}
\hline \multirow{2}{*}{ Borohydrides } & \multicolumn{3}{|c|}{ Hydrogen (mass\%) } & \multicolumn{2}{|c|}{$\begin{array}{c}\text { Conditions: temp (K) } \\
\text { [pressure (MPa)] }\end{array}$} & \multirow{2}{*}{ Reference } \\
\hline & Ideal & $\begin{array}{c}\text { Obs } \\
\text { (First Dehyd) }\end{array}$ & $\begin{array}{c}\text { Obs } \\
\text { (Rehyd) }\end{array}$ & $\begin{array}{c}\text { First } \\
\text { Dehyd }\end{array}$ & Rehyd & \\
\hline $\mathrm{ZrLi}\left(\mathrm{BH}_{4}\right)_{5}$ & 11.7 & & & $595-873$ & & [107] \\
\hline $\mathrm{ZrLi}_{2}\left(\mathrm{BH}_{4}\right)_{6}$ & 12.5 & & & $650-873$ & & [107] \\
\hline $\mathrm{LiK}\left(\mathrm{BH}_{4}\right)_{2}$ & 10.6 & & & $653-$ & & {$[108]$} \\
\hline $\mathrm{LiSc}\left(\mathrm{BH}_{4}\right)_{4}$ & 14.5 & $4.38-6.4^{m}$ & & $415-673$ & $673[7]$ & {$[109,111]$} \\
\hline $\mathrm{LiZn}_{2}\left(\mathrm{BH}_{4}\right)_{5} *$ & 9.5 & & & $238-473$ & & [112] \\
\hline $\mathrm{NaZn}_{2}\left(\mathrm{BH}_{4}\right)_{5} *$ & 8.8 & & & $241-$ & & {$[112]$} \\
\hline $\mathrm{NaSc}\left(\mathrm{BH}_{4}\right)_{4}$ & 12.7 & $0.97^{m}$ & & $440-750$ & & [113] \\
\hline $\mathrm{Na}_{2} \mathrm{Mn}\left(\mathrm{BH}_{4}\right)_{4}$ & 10.1 & 2.9 & & 393 & & [114] \\
\hline $\mathrm{KSc}\left(\mathrm{BH}_{4}\right)_{4}$ & 11.2 & $4.4^{p}$ & & $470-580$ & & [117] \\
\hline $\mathrm{LiBH}_{4} / \mathrm{Mg}\left(\mathrm{BH}_{4}\right)_{2}$ & 16.0 & 12.5 & 2.5 & $513-773$ & $673[10]$ & {$[115]$} \\
\hline $\begin{array}{l}\mathrm{xLiBH}_{4}+(1-\mathrm{x}) \mathrm{Ca}\left(\mathrm{BH}_{4}\right)_{2} \\
(0<\mathrm{x}<1)\end{array}$ & $9.6-18.5$ & $\begin{array}{c}10(\mathrm{x}=0.4 \\
0.6)\end{array}$ & $\begin{array}{c}4(\mathrm{x}= \\
0.4)\end{array}$ & $473-773$ & $673[9]$ & [116] \\
\hline
\end{tabular}

* represents that the release of $\mathrm{B}_{2} \mathrm{H}_{6}$ in the decomposition process; ${ }^{m}$ indicates the value referred to the mixture of metal borohydride with side products, while ${ }^{p}$ indicates the value referred to the pure metal borohydride. 
The other approach to reducing enthalpy change $\Delta H_{\text {deh }}$ is the stabilization of dehydrogenated products by the combination of $M\left(\mathrm{BH}_{4}\right)_{n}$ with elements, metal hydrides, complex hydrides, and so on. A typical example for this approach is the $2 \mathrm{LiBH}_{4}+\mathrm{MgX}$ system [118]. Pure $\mathrm{LiBH}_{4}$ releases approximately 13.8 mass $\%$ of hydrogen according to the following reaction:

$$
\mathrm{LiBH}_{4}=\mathrm{LiH}+\mathrm{B}+3 / 2 \mathrm{H}_{2}
$$

The enthalpy and entropy for Equation 5 have been predicted to be $66.6 \mathrm{~kJ} \mathrm{~mol}^{-1} \mathrm{H}_{2}$ and 97.4 $\mathrm{J} \mathrm{K}^{-1} \mathrm{~mol}^{-1}$ [119], respectively, which means $T_{\mathrm{d}}$ (in $0.1 \mathrm{MPa}_{2}$ ) is approximately $683 \mathrm{~K}$. This temperature is too high for practical applications, although the combination with $\mathrm{Mg}$-based compounds clearly results in a large reduction of $\Delta H_{\text {deh. }}$. Dehydrogenation of the $\mathrm{LiBH}_{4} / \mathrm{MgH}_{2}$ system proceeds as follows:

$$
2 \mathrm{LiBH}_{4}+\mathrm{MgH}_{2}=2 \mathrm{LiH}+\mathrm{MgB}_{2}+4 \mathrm{H}_{2}
$$

In this case, due to the formation of $\mathrm{MgB}_{2}, \Delta H_{\mathrm{deh}}$ was reduced to $45.8 \mathrm{~kJ} \mathrm{~mol}^{-1} \mathrm{H}_{2}$ and $T_{\mathrm{d}}$ (in $0.1 \mathrm{MPa} \mathrm{H}_{2}$ ) decreased to approximately $441 \mathrm{~K}$ [120]. At the same time, a significant destabilization of $\mathrm{LiBH}_{4}$ due to combination with the $\mathrm{LiNH}_{2}$ system was reported [121], as indicated by the much higher dehydrogenation pressure of the combined materials than that of $\mathrm{LiBH}_{4}$ alone. Due to these significant destabilization effects, a large number of combination materials have been developed. The recent progress on these combination systems [120-185] is summarized in Table 3 .

This approach not only reduces the enthalpy of the dehydrogenation, which decreases $T_{\mathrm{d}}$, but also kinetically enhances the rehydrogenation reaction. That is, in contrast to the formation of pure $\mathrm{LiBH}_{4}$ (from right to left in Equation 5) discussed in Section 2, $\mathrm{LiBH}_{4}$ and $\mathrm{MgH}_{2}$ form simultaneously (from right to left in Equation 6) under fairly moderate conditions: $5 \mathrm{MPa}$ hydrogen pressure in the temperature range 523-573 $\mathrm{K}$ [136]. The difference between these two reactions is attributed to the different crystal structures and boron bonding of pure boron and $\mathrm{MgB}_{2}$, as shown in Figure 4. That is, in pure boron, the common building blocks are icosahedral units that consist of 12 boron atoms, and each atom is connected to five other atoms via covalent bonds. By contrast, in $\mathrm{MgB}_{2}$, each boron atom is connected to a maximum of three other boron atoms. The recent activities of the above-mentioned metal boride systems [136,186-192] are summarized in Table 4.

Figure 4. Schematic illustrations of (a) $\mathrm{B}_{12}$ icosahedral unit in boron and (b) layer structure of $\mathrm{MgB}_{2}$.
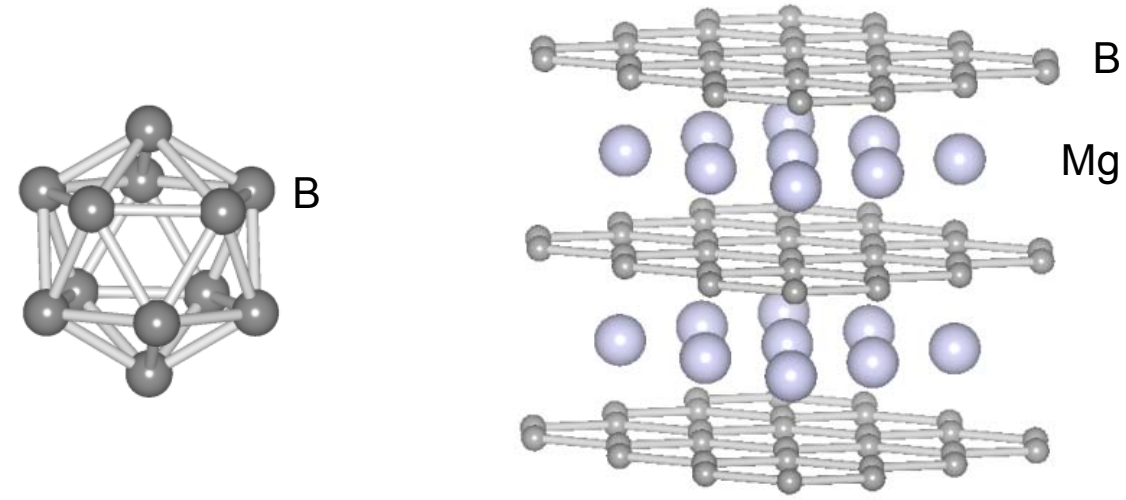

(a)

(b) 
Table 3. Hydrogen storage properties of the combination systems of $M\left(\mathrm{BH}_{4}\right)_{n}$ with metal hydrides, complex hydrides, metals, etc.

\begin{tabular}{|c|c|c|c|c|c|c|c|}
\hline \multirow{2}{*}{ Reaction } & \multicolumn{3}{|c|}{ Hydrogen (mass\%) } & \multicolumn{2}{|c|}{$\begin{array}{l}\text { Conditions: temp (K) } \\
\text { [pressure (MPa)] }\end{array}$} & \multirow{2}{*}{$\begin{array}{c}\text { Theor/Exp } \\
\Delta H_{\text {dehyd }} \\
\left(k^{-1} \mathrm{~mol}^{-1} \mathrm{H}_{2}\right)\end{array}$} & \multirow{2}{*}{ Reference } \\
\hline & Ideal & $\begin{array}{c}\text { Obs } \\
\text { (First Dehyd) }\end{array}$ & $\begin{array}{c}\text { Obs } \\
\text { (Rehyd) }\end{array}$ & $\begin{array}{c}\text { First } \\
\text { Dehyd }\end{array}$ & Rehyd & & \\
\hline $\begin{array}{l}\mathrm{LiBH}_{4}+1 / 2 \mathrm{MgH}_{2}=\mathrm{LiH}+1 / 2 \mathrm{MgB}_{2}+ \\
2 \mathrm{H}_{2}\end{array}$ & 11.5 & $8.0-10.6$ & $8.0-10$ & $543-723$ & $503-723[10]$ & $\begin{array}{l}\text { T } 50.4-66.8 / \\
\quad \text { E } 40.5\end{array}$ & $\begin{array}{c}{[29,120,124} \\
134-136,142,145,156, \\
168,172,186]\end{array}$ \\
\hline $\mathrm{LiBH}_{4}+2 \mathrm{LiNH}_{2}=\mathrm{Li}_{3} \mathrm{BN}_{2}+4 \mathrm{H}_{2}$ & 11.9 & $7.8-12$ & 0.1 & $622-673$ & $573[5]$ & E 23 & $\begin{array}{c}{[121,123,124,} \\
127-130,132,149, \\
160,166] \\
\end{array}$ \\
\hline $\mathrm{LiBH}_{4}+1 / 2 \mathrm{Al}=\mathrm{LiH}+1 / 2 \mathrm{AlB}_{2}+3 / 2 \mathrm{H}_{2}$ & 8.6 & $6.8-7.2$ & $5-7.6$ & $553-823$ & $\begin{array}{c}573-773 \\
{[10-15.5]}\end{array}$ & Т $18.8-57.9$ & {$[134,135,137,163-165]$} \\
\hline $\begin{array}{l}\mathrm{LiBH}_{4}+1 / 2 \mathrm{LiAlH}_{4}=3 / 2 \mathrm{LiH}+1 / 2 \mathrm{AlB}_{2} \\
+9 / 4 \mathrm{H}_{2}\end{array}$ & 11.1 & $6-10$ & $4.8-5.1$ & $327-773$ & $\begin{array}{c}623-873 \\
{[4-7]}\end{array}$ & & [157] \\
\hline $\begin{array}{l}\mathrm{LiBH}_{4}+1 / 2 \mathrm{Mg}=\mathrm{LiH}+1 / 2 \mathrm{MgB}_{2}+ \\
3 / 2 \mathrm{H}_{2}\end{array}$ & 8.9 & 5.6 & & $648-773$ & & T 46.4 & {$[134,135]$} \\
\hline $\begin{array}{l}\mathrm{LiBH}_{4}+1 / 6 \mathrm{CaH}_{2}=\mathrm{LiH}+1 / 6 \mathrm{CaB}_{6}+ \\
10 / 6 \mathrm{H}_{2}\end{array}$ & 11.7 & $5.1-11.1$ & $9-11.1$ & $423-773$ & $673[10]$ & Т 45.4-66.5 & $\begin{array}{c}{[19,135,137,142,144,} \\
168]\end{array}$ \\
\hline $\mathrm{LiBH}_{4}+1 / 2 \mathrm{ScH}_{2}=\mathrm{LiH}+1 / 2 \mathrm{ScB}_{2}+2 \mathrm{H}_{2}$ & 8.9 & 4.5 & & $553-723$ & & Т 34.1 & {$[134,135,142,143]$} \\
\hline $\begin{array}{l}\mathrm{LiBH}_{4}+1 / 6 \mathrm{CeH}_{2}=\mathrm{LiH}+1 / 6 \mathrm{CeB}_{6}+ \\
10 / 6 \mathrm{H}_{2}\end{array}$ & 7.4 & $6.1-6.2$ & 6.0 & $443-723$ & $623[10]$ & Т 44.1 & {$[144,168,177]$} \\
\hline $\mathrm{LiBH}_{4}+1 / 4 \mathrm{YH}_{3}=\mathrm{LiH}+1 / 4 \mathrm{YB}_{4}+15 / 8 \mathrm{H}_{2}$ & 8.4 & 7.2 & & 623 & & & {$[168]$} \\
\hline $\begin{array}{l}\mathrm{LiBH}_{4}+1 / 4 \mathrm{MgH}_{2}+1 / 4 \mathrm{Al}=\mathrm{LiH}+1 / 4 \\
\mathrm{MgAlB}_{4}+7 / 4 \mathrm{H}_{2}\end{array}$ & 10.0 & 9.4 & 6 & $533-673$ & $673[4]$ & E 57 & [159] \\
\hline $\mathrm{Ca}\left(\mathrm{BH}_{4}\right)_{2}+\mathrm{MgH}_{2}=\mathrm{CaH}_{2}+\mathrm{MgB}_{2}+4 \mathrm{H}_{2}$ & 8.4 & 7.1 & & $623-723$ & & T 47 & [135] \\
\hline
\end{tabular}


Table 3. Cont.

\begin{tabular}{|c|c|c|c|c|c|c|c|}
\hline $\begin{array}{l}\mathrm{Ca}\left(\mathrm{BH}_{4}\right)_{2}+\mathrm{MgH}_{2}=2 / 3 \mathrm{CaH}_{2}+1 / 3 \mathrm{CaB}_{6}+ \\
\mathrm{Mg}+13 / 3 \mathrm{H}_{2}\end{array}$ & 9.1 & 8.1 & 5.5 & $593-773$ & $623[9]$ & Т 45 & [187] \\
\hline $\begin{array}{l}\mathrm{Mg}\left(\mathrm{BH}_{4}\right)_{2}+\mathrm{LiNH}_{2}=\mathrm{Li}-\mathrm{Mg}+ \\
\text { BN-related }+5 \mathrm{H}_{2}\end{array}$ & 13.1 & 11.4 & & $433-873$ & & & {$[174]$} \\
\hline $\begin{array}{l}\mathrm{NaBH}_{4}+1 / 2 \mathrm{MgH}_{2}=\mathrm{Na}+1 / 2 \mathrm{MgB}_{2}+ \\
5 / 2 \mathrm{H}_{2}\end{array}$ & 9.9 & 9 & 6 & $330-723$ & $723[5]$ & Т 62 & {$[183,186]$} \\
\hline $\mathrm{NaBH}_{4}+2 \mathrm{NaNH}_{2}=\mathrm{Na}_{3} \mathrm{BN}_{2}+4 \mathrm{H}_{2} *$ & 7.0 & & & $500-773$ & & & {$[173]$} \\
\hline \multicolumn{2}{|c|}{$\begin{array}{l}x \mathrm{LiBH}_{4}+y\left(\mathrm{LiNH}_{2}\right)_{2}+z\left(\mathrm{MgH}_{2}\right)=\mathrm{Li}_{3} \mathrm{BN}_{2}+\mathrm{Mg}_{3} \mathrm{~N}_{2}+ \\
\mathrm{LiH}+\mathrm{H}_{2}\end{array}$} & & & & \multirow{6}{*}{$\begin{array}{l}453 \\
{[15]}\end{array}$} & & \multirow{6}{*}[140,141,155]{} \\
\hline$x: y: z=2: 1: 1$ & 13.0 & 8.5 & 2.9 & $413-743$ & & & \\
\hline $2: 0.5: 1$ & 13.6 & 8.6 & 3.7 & $413-743$ & & & \\
\hline $2: 1: 2$ & 11.8 & 6.6 & 3.1 & $428-743$ & & & \\
\hline $1: 1: 1$ & 11.3 & 5.6 & 2.7 & $428-743$ & & & \\
\hline $3: 1: 1.5$ & 13.4 & 9.1 & & $413-743$ & & & \\
\hline
\end{tabular}

* represents that the release of $\mathrm{NH}_{3}$ in the decomposition process: $\mathrm{T}$ and $\mathrm{E}$ represent the theoretic and experimental values, respectively. 
Table 4. Hydrogen storage properties of metal borides and metal hydrides systems.

\begin{tabular}{|c|c|c|c|c|c|c|}
\hline \multirow{2}{*}{ Reaction } & \multicolumn{3}{|c|}{ Hydrogen (mass\%) } & \multicolumn{2}{|c|}{$\begin{array}{l}\text { Conditions: temp (K) } \\
\text { [pressure (MPa)] }\end{array}$} & \multirow{2}{*}{ Reference } \\
\hline & Ideal & $\begin{array}{c}\text { Obs } \\
\text { (First Hyd) }\end{array}$ & $\begin{array}{c}\text { Obs } \\
\text { (Dehyd) }\end{array}$ & First Hyd & Dehyd & \\
\hline $\mathrm{LiH}+1 / 2 \mathrm{MgB}_{2}+2 \mathrm{H}_{2}=\mathrm{LiBH}_{4}+1 / 2 \mathrm{MgH}_{2}$ & 11.5 & $3.2-11$ & $3.0-8.0$ & $\begin{array}{c}538-673 \\
{[9-35]} \\
\end{array}$ & $\begin{array}{c}538-723 \\
{[0-0.6]} \\
\end{array}$ & $\begin{array}{c}{[120,145,} \\
182,186,187]\end{array}$ \\
\hline $\begin{array}{l}\mathrm{LiF}+1 / 2 \mathrm{MgB}_{2}+\mathrm{H}_{2}=\mathrm{LiBH}_{4-y} \mathrm{~F}_{y}+1 / 2 \mathrm{MgF}_{2}+ \\
\mathrm{LiH}_{1-\chi} \mathrm{F}_{X}\end{array}$ & & 6.6 & 6.4 & $663[6]$ & $693[0.5]$ & [189] \\
\hline $\begin{array}{l}\mathrm{Li}_{7} \mathrm{Sn}_{2}+7 / 2 \mathrm{MgB}_{2}+14 \mathrm{H}_{2}=7 \mathrm{LiBH}_{4}+7 / 4 \mathrm{Mg}_{2} \mathrm{Sn}+ \\
1 / 4 \mathrm{Sn}\end{array}$ & 5.9 & $2.5-3$ & & $\begin{array}{l}573-673 \\
{[20-30]}\end{array}$ & & [186] \\
\hline $\mathrm{CaH}_{2}+\mathrm{MgB}_{2}+4 \mathrm{H}_{2}=\mathrm{Ca}\left(\mathrm{BH}_{4}\right)_{2}+\mathrm{MgH}_{2}$ & 8.4 & $4.7-7$ & & $573-673[20-35]$ & & {$[186,187]$} \\
\hline $\mathrm{NaH}+1 / 2 \mathrm{MgB}_{2}+2 \mathrm{H}_{2}=\mathrm{NaBH}_{4}+1 / 2 \mathrm{MgH}_{2}$ & 7.9 & $6.2-6.7$ & & $573-673[20-35]$ & & {$[186]$} \\
\hline $1 / 3 \mathrm{CaB}_{6}+2 / 3 \mathrm{CaH}_{2}+10 / 3 \mathrm{H}_{2}=\mathrm{Ca}\left(\mathrm{BH}_{4}\right)_{2}$ & 9.6 & 4.8 & & $623[10]$ & $543-573$ & {$[186]$} \\
\hline $\begin{array}{l}2 / 3 \mathrm{CaH}_{2}+1 / 3 \mathrm{CaB}_{6}+1 / 2 \mathrm{Mg}+23 / 6 \mathrm{H}_{2}=\mathrm{Ca}\left(\mathrm{BH}_{4}\right)_{2} \\
+1 / 2 \mathrm{MgH}_{2}\end{array}$ & 9.3 & & $4.9-5.9$ & $623-673[9]$ & & [192] \\
\hline $\begin{array}{l}\mathrm{MgNi}_{2.5} \mathrm{~B}_{2}+2 \mathrm{LiH}+4 \mathrm{MgH}_{2}+4 \mathrm{H}_{2}=2 \mathrm{LiBH}_{4}+ \\
5 / 2 \mathrm{Mg}_{2} \mathrm{NiH}_{4}\end{array}$ & 2.5 & 1.0 & 1.0 & $623[16]$ & $613[0.4]$ & [167] \\
\hline $\mathrm{MgB}_{2}+4 \mathrm{H}_{2}=\mathrm{Mg}\left(\mathrm{BH}_{4}\right)_{2}$ & 14.9 & & 11.0 & $673[95]$ & & {$[73,74]$} \\
\hline
\end{tabular}




\subsection{Promoting Kinetics}

$M\left(\mathrm{BH}_{4}\right)_{n}$ dehydrogenates via stepwise reactions accompanied by the formation of intermediate compounds. Although the rate-controlling step has not been determined, the complicated dehydrogenation feature makes the promotion of kinetics rather challenging. There are two approaches that have been extensively studied to reduce the reaction barrier: (a) appropriate additives with catalytic abilities and (b) the nanoconfinement approach.

Complex hydrides including alanates, amides, and borohydrides are commonly known to exhibit sluggish kinetics. Since Bogdanovic et al. found that the addition of Ti-based compounds significantly promoted the dehydrogenation-rehydrogenation reactions of $\mathrm{NaAlH}_{4}$ [193], the development of complex hydrides for hydrogen storage has significantly increased. Stimulated by this finding, a large number of additives from oxides, halides, metals, and carbon-based materials to $M\left(\mathrm{BH}_{4}\right)_{n}$ have been examined [19,20,58,87,101,130,144,150,161,168,170,171,191,194-210]; the corresponding dehydrogenation and rehydrogenation properties are summarized in Table 5. For instance, the most effective additive for $\mathrm{LiBH}_{4}$ was found to be the mixture of $0.2 \mathrm{MgCl}_{2}+0.1 \mathrm{TiCl}_{3}$, in which approximately 5 mass $\%$ of hydrogen was released from $333 \mathrm{~K}$ and 4.5 mass $\%$ of hydrogen was rehydrogenated at $873 \mathrm{~K}$ in $7 \mathrm{MPa}$ $\mathrm{H}_{2}$ [195]. The addition of $\mathrm{TiCl}_{3}$ was also proved to be effective for $\mathrm{Mg}\left(\mathrm{BH}_{4}\right)_{2}$, the starting dehydrogenation temperature of which was reduced to $361 \mathrm{~K}$ [58]. Titanium isopropoxide was reported to be an effective additive for the combination system of $2 \mathrm{LiBH}_{4}+\mathrm{MgH}_{2}$ [136]. According to the X-ray absorption spectroscopy analysis, titanium isopropoxide was demonstrated to form a disordered $\mathrm{TiO}_{2}$ anatase during ball milling with $2 \mathrm{LiBH}_{4}+\mathrm{MgH}_{2}$. After several dehydrogenationrehydrogenation cycles, $\mathrm{Ti}$ species were demonstrated to change to $\mathrm{Ti}_{2} \mathrm{O}_{3}$ and $\mathrm{TiB}_{2}$ [181]. Similar phenomena were reported for most additives, and the oxidation states of the initial additives vary with cycling experiments, though the catalytic mechanism is still uncertain.

The dehydrogenation-rehydrogenation reactions of $M\left(\mathrm{BH}_{4}\right)_{n}$ are accompanied by the diffusion of constituent elements such as $M, \mathrm{~B}$, and $\mathrm{H}$. The relatively high reaction temperature further prolongs the diffusion distance and enlarges the crystallite size of $M$ and $\mathrm{B}$, thus further degrading the hydrogen storage properties. Fabricating and maintaining the nanosized metal borohydrides is expected to be an effective way to overcome the aforementioned barriers. One known approach is to incorporate hydrogen storage materials into nanoporous materials. It was first applied in the $\mathrm{NH}_{3} \mathrm{BH}_{3}$ system [211] and good improvement was obtained: The dehydrogenation temperature was largely decreased and the amount of borazine gas (an impurity) was significantly reduced. Recently, this approach was introduced for $M\left(\mathrm{BH}_{4}\right)_{n}$ materials, and some recent achievements [160,212-222] are summarized in Table 6.

By the incorporation into nanoporous carbon scaffolds with a 13-nm pore size, the dehydrogenation rates of $\mathrm{LiBH}_{4}$ were found to be up to 50 times faster than those in the bulk materials measured at $573 \mathrm{~K}$ [212]. In addition, the capacity loss over three cycles was reduced from $72 \%$ for bulk $\mathrm{LiBH}_{4}$ to $\sim 40 \%$ for nanoconfined $\mathrm{LiBH}_{4}$. Further, a recent report confirmed the synergetic effects of nanoconfinement and $\mathrm{Ni}$ addition on the dehydrogenation and rehydrogenation properties of $\mathrm{LiBH}_{4}$. The nanoconfinement of the mixture of $\mathrm{LiBH}_{4}$ and $\mathrm{Ni}$ addition in a nanoporous carbon scaffold shows a higher rehydrogenation rate and larger rehydrogenation amount than those of the samples without $\mathrm{Ni}$ addition at $593 \mathrm{~K}$ in a hydrogen pressure of $4 \mathrm{MPa}$ [220]. This suggests that the combination of nanoconfinement and additives would be a valid way to improve the hydrogen storage properties of $M\left(\mathrm{BH}_{4}\right)_{n}$. 
Table 5. Hydrogen storage properties of $M\left(\mathrm{BH}_{4}\right)_{n}$ with additives (oxides, halides, carbon, etc.).

\begin{tabular}{|c|c|c|c|c|c|c|c|c|}
\hline \multirow{2}{*}{$M\left(\mathrm{BH}_{4}\right)_{\mathrm{n}}$} & \multicolumn{2}{|l|}{ Additives } & \multicolumn{2}{|c|}{ Hydrogen (mass\%) } & \multicolumn{2}{|c|}{$\begin{array}{c}\text { Conditions: temp (K) } \\
\text { [pressure (MPa)] }\end{array}$} & \multirow{2}{*}{$\begin{array}{c}\text { Toxic } \\
\text { Byproduct }\end{array}$} & \multirow{2}{*}{ Reference } \\
\hline & Type & Amount & $\begin{array}{c}\text { Obs } \\
\text { (First Dehyd) }\end{array}$ & $\begin{array}{c}\text { Obs } \\
\text { (Rehyd) }\end{array}$ & First Dehyd & Rehyd & & \\
\hline \multirow{20}{*}{$\mathrm{LiBH}_{4}$} & $\mathrm{SiO}_{2}$ & $10-25$ mass $\%$ & $9-10^{m}$ & & $423-873$ & & & {$[19,20,204]$} \\
\hline & $\mathrm{TiO}_{2}$ & $25-80$ mass $\%$ & $4-9^{m}$ & $3.5-8.3^{m}$ & $373-873$ & 873 [7-10] & & {$[197,209]$} \\
\hline & $\mathrm{ZrO}_{2}$ & 25 mass $\%$ & $8-9^{m}$ & & $448-873$ & & & [197] \\
\hline & $\mathrm{V}_{2} \mathrm{O}_{3}$ & 25 mass $\%$ & $8-9^{m}$ & $8^{m}$ & $448-873$ & $873[10]$ & & [197] \\
\hline & $\mathrm{SnO}_{2}$ & 25 mass $\%$ & $8-9^{m}$ & & $448-873$ & & & [197] \\
\hline & $\mathrm{Nb}_{2} \mathrm{O}_{5}$ & $50-80$ mass $\%$ & $4-6^{m}$ & & $373-873$ & & & [209] \\
\hline & $\mathrm{Fe}_{2} \mathrm{O}_{3}$ & $50-66.7$ mass $\%$ & $5.7-9^{m}$ & & $373-873$ & & & [209] \\
\hline & $\mathrm{V}_{2} \mathrm{O}_{5}$ & $50-66.7$ mass $\%$ & $5.7-9^{m}$ & & $373-873$ & & & [209] \\
\hline & $\mathrm{TiCl}_{3}$ & 10-88 mass $\%$ & $2.8-9.2^{m}$ & $3.4^{m}$ & $373-873$ & $773[7]$ & $\mathrm{B}_{2} \mathrm{H}_{6}$ & {$[197,208]$} \\
\hline & $\mathrm{CoCl}_{2}$ & $5-100 \mathrm{~mol} \%$ & $10.5-18.3^{p}$ & & $503-873$ & & $\mathrm{~B}_{2} \mathrm{H}_{6}$ & [213] \\
\hline & $\mathrm{TiH}_{2}$ & $10-50 \mathrm{~mol} \%$ & $6-15^{m}$ & $2.5-4.5^{m}$ & $573-873$ & $773[7]$ & & [208] \\
\hline & $\mathrm{TiF}_{3}$ & $10-50 \mathrm{~mol} \%$ & $6.4-14^{m}$ & $0.2-4.0^{m}$ & $373-773$ & $\begin{array}{c}623-773 \\
{[7-10]} \\
\end{array}$ & $\mathrm{B}_{2} \mathrm{H}_{6}$ & {$[208,211]$} \\
\hline & $\mathrm{ZnF}_{2}$ & $10-50 \mathrm{~mol} \%$ & $3.7-7^{m}$ & $1-4^{m}$ & $393-773$ & $773[7]$ & $\mathrm{B}_{2} \mathrm{H}_{6}$ & {$[208]$} \\
\hline & mixture of $\mathrm{MgCl}_{2} / \mathrm{TiCl}_{3}$ & $30 \mathrm{~mol} \%$ & $5^{m}$ & $4.5^{m}$ & $333-873$ & $873[7]$ & & {$[198]$} \\
\hline & $\mathrm{Mg}$ & $10-20 \mathrm{~mol} \%$ & $9^{m}$ & & $333-873$ & & & [198] \\
\hline & $\mathrm{Al}$ & $20 \mathrm{~mol} \%$ & $7.8^{m}$ & $3.5^{m}$ & $353-873$ & $873[10]$ & & [198] \\
\hline & $\mathrm{Sc}$ & $33 \mathrm{~mol} \%$ & $2.9^{m}$ & & $673-773$ & & & [134] \\
\hline & $\mathrm{Ti}$ & $33 \mathrm{~mol} \%$ & $2.5^{m}$ & & $673-773$ & & & [134] \\
\hline & $\mathrm{V}$ & $33 \mathrm{~mol} \%$ & $4.4^{m}$ & & $673-773$ & & & [134] \\
\hline & $\mathrm{Cr}$ & $33 \mathrm{~mol} \%$ & $4.4^{m}$ & & $673-773$ & & & [134] \\
\hline \multirow{5}{*}{$\mathrm{LiBH}_{4}$} & $\mathrm{MgH}_{2}$ & 80 mass $\%$ & $8.8-9.2^{m}$ & $8.5^{m}$ & $627-853$ & $673[10]$ & & {$[126,172]$} \\
\hline & graphite & 30 mass $\%$ & $9.9^{p}$ & $2.6^{p}$ & $663-773$ & $673[10]$ & & [212] \\
\hline & activated carbon & 30 mass $\%$ & $11.2^{p}$ & $4.6^{p}$ & $623-773$ & $673[10]$ & & [212] \\
\hline & single-walled carbon nanotubes & $30 \operatorname{mass} \%$ & $11.4-12.3^{p}$ & $3.7^{p}$ & $553-773$ & $673[10]$ & & {$[205,212]$} \\
\hline & single-walled carbon nanotubes & $9.1-50$ mass $\%$ & $5-11.8^{p}$ & $3.7-6.1^{p}$ & 723 (iso) & $673[10]$ & & {$[207]$} \\
\hline
\end{tabular}


Table 5. Cont.

\begin{tabular}{|c|c|c|c|c|c|c|c|c|}
\hline & mesoporous carbon & 50 mass $\%$ & $7^{m}$ & $6^{m}$ & $605-873$ & $623[3]$ & & [200] \\
\hline & mixture of $\mathrm{TiF}_{3} / \mathrm{SiO}_{2}$ & 50 mass $\%$ & $8.3^{m}$ & $4^{m}$ & $343-823$ & $773[4.5]$ & & [204] \\
\hline & $\mathrm{Pt} / \mathrm{C}$ & $10-50$ mass $\%$ & $9.2-15.7^{m}$ & $6.1^{m}$ & $553-973$ & $873[3]$ & & [206] \\
\hline \multirow{11}{*}{$\begin{array}{l}\mathrm{LiBH}_{4}+ \\
1 / 2 \mathrm{MgH}_{2}\end{array}$} & Ti-iso & $5-10 \mathrm{~mol} \%$ & $6.5-8.4^{m}$ & $6.0^{\mathrm{m}}$ & 673 (iso) & $623[5]$ & & {$[170,136]$} \\
\hline & Zr-iso & $10 \mathrm{~mol} \%$ & $5.5^{\mathrm{m}}$ & & 673 (iso) & & & {$[150]$} \\
\hline & $\mathrm{ZrCl}_{4}$ & $10 \mathrm{~mol} \%$ & $7.5^{m}$ & & 673 (iso) & & & {$[150]$} \\
\hline & $\mathrm{SiO}_{2}$ & $5 \mathrm{~mol} \%$ & $9.3^{m}$ & & 673 (iso) & & & {$[136]$} \\
\hline & $\mathrm{VCl}_{3}$ & $5 \mathrm{~mol} \%$ & $9.1^{m}$ & & 673 (iso) & & & {$[136]$} \\
\hline & graphite & 10 mass $\%$ & $9.5^{p}$ & & 723 (iso) & & & [168] \\
\hline & carbon nanofibers & 10 mass $\%$ & $10.0^{p}$ & & 723 (iso) & & & [168] \\
\hline & activated carbon & 10 mass $\%$ & $10.0^{p}$ & & 723 (iso) & & & [168] \\
\hline & single-walled carbon nanotubes & 10 mass $\%$ & $10.0^{p}$ & $6.7^{p}$ & $\sim 573-773$ & $673[7.5]$ & & [168] \\
\hline & muti-walled carbon nanotubes & 10 mass $\%$ & $10.0^{p}$ & & 723 (iso) & & & {$[168]$} \\
\hline & $\mathrm{TiF}_{3}$ & $5 \mathrm{~mol} \%$ & $9.7^{p}$ & & 573 (iso) & & & {$[72]$} \\
\hline \multirow{4}{*}{$\mathrm{Li}_{3} \mathrm{BN}_{2} \mathrm{H}_{8}$} & $\mathrm{Pt} /$ Vulcan carbon & $1-10$ mass $\%$ & $9-13^{m}$ & $1.4^{m}$ & $388-673$ & $423[8.4]$ & $\mathrm{NH}_{3}$ & {$[130]$} \\
\hline & $\mathrm{Pd}$ & $5-10$ mass $\%$ & $11.8-13^{m}$ & & $473-673$ & & & {$[130]$} \\
\hline & $\mathrm{PdCl}_{2}$ & 8.3 mass $\%$ & $10.4^{m}$ & & $473-673$ & & & {$[130]$} \\
\hline & $\mathrm{CoCl}_{2}$ & 5 mass $\%$ & $8-10^{m}$ & & $388-493$ & & & [149] \\
\hline $\mathrm{Li}_{4} \mathrm{BN}_{3} \mathrm{H}_{10}$ & $\mathrm{NiCl}_{2}$ & 11 mass $\%$ & $7.6^{p}$ & & $433-673$ & & $\mathrm{NH}_{3}$ & [161] \\
\hline $\begin{array}{c}\mathrm{Ca}\left(\mathrm{BH}_{4}\right)_{2}+ \\
\mathrm{MgH}_{2}\end{array}$ & Ti-iso & 1 mass $\%$ & $7.1^{m}$ & & $523-723$ & & & {$[190]$} \\
\hline \multirow{4}{*}{$\mathrm{Ca}\left(\mathrm{BH}_{4}\right)_{2}$} & $\mathrm{NbF}_{5}$ & $2 \mathrm{~mol} \%$ & $8.3^{\mathrm{m}}$ & $4.6-5.0^{m}$ & $\sim 593-823$ & 623 [9] & & [87] \\
\hline & $\mathrm{NbCl}_{5}$ & $2 \mathrm{~mol} \%$ & $4.1-5.0^{m}$ & $3.1-4.5^{m}$ & $\sim 593-823$ & 623 [9] & & {$[87]$} \\
\hline & $\mathrm{TiF}_{3}$ & $2 \mathrm{~mol} \%$ & $4.1-5.0^{m}$ & $2.5-4.2^{m}$ & $\sim 593-823$ & 623 [9] & & [87] \\
\hline & $\mathrm{TiCl}_{3}$ & $2 \mathrm{~mol} \%$ & $4.1-5.0^{\mathrm{m}}$ & $3.5-4.4^{m}$ & $\sim 593-823$ & 623 [9] & & [87] \\
\hline \multirow{2}{*}{$\mathrm{Mg}\left(\mathrm{BH}_{4}\right)_{2}$} & $\mathrm{TiCl}_{3}$ & 25 mass $\%$ & $13.7^{p}$ & & $361-800$ & & & {$[58]$} \\
\hline & $\mathrm{TiO}_{2}$ & 25 mass $\%$ & $13.7^{p}$ & & $483-800$ & & & [58] \\
\hline
\end{tabular}

${ }^{m}$ indicates the value referred to the mixture of metal borohydride with side products, while ${ }^{p}$ indicates the value referred to the pure metal borohydride. 
Table 6. Hydrogen storage properties of $M\left(\mathrm{BH}_{4}\right)_{n}$ confined by nanoporous materials.

\begin{tabular}{|c|c|c|c|c|c|c|c|}
\hline \multirow{2}{*}{ Reaction } & \multirow{2}{*}{$\begin{array}{l}\text { Type of Nano Scaffold (size } \\
\text { (nm)) }\end{array}$} & \multirow{2}{*}{$\begin{array}{l}\text { Loading Ratio } \\
\text { (mass\%) }\end{array}$} & \multicolumn{2}{|c|}{ Hydrogen (mass\%) } & \multicolumn{2}{|c|}{$\begin{array}{l}\text { Conditions: temp (K) } \\
\text { [pressure (MPa)] }\end{array}$} & \multirow{2}{*}{ Referenc } \\
\hline & & & $\begin{array}{c}\text { Obs } \\
\text { (First Dehyd) }\end{array}$ & $\begin{array}{c}\text { Obs } \\
\text { (Rehyd) }\end{array}$ & $\begin{array}{c}\text { First } \\
\text { Dehyd }\end{array}$ & Rehyd & \\
\hline \multirow{4}{*}{$\mathrm{LiBH}_{4}=\mathrm{LiH}+\mathrm{B}+3 / 2 \mathrm{H}_{2}$} & $\begin{array}{c}\text { Nanoporous Carbon } \\
(13-25)\end{array}$ & $25-50$ & $4.6-6.4^{m}$ & & $503-873$ & $673[10]$ & [212] \\
\hline & $\begin{array}{c}\text { Activated carbon } \\
(1.75-3.2)\end{array}$ & 28.4 & $11.2^{p}$ & $6.6^{p}$ & $493-773$ & $573[5]$ & [213] \\
\hline & $\begin{array}{c}\text { Mesoporous carbon } \\
\text { (4) }\end{array}$ & 33 & $3.4^{m}$ & & $473-773$ & & [214] \\
\hline & $\begin{array}{c}\text { Nanoporous Carbon } \\
\text { (2) }\end{array}$ & & $8.8^{p}$ & & $493-673$ & & [219] \\
\hline \multirow{2}{*}{$\mathrm{Li}_{3} \mathrm{BN}_{2} \mathrm{H}_{8}=\mathrm{Li}_{3} \mathrm{BN}_{2}+4 \mathrm{H}_{2} *$} & $\begin{array}{c}\text { Nanoporous carbon } \\
\text { scaffolds }(16 \pm 3)\end{array}$ & 33 & $11.1^{p}$ & $3.8^{p}$ & $523-673$ & $573[5]$ & {$[160]$} \\
\hline & activated carbon AX-21 (2) & 33 & $10.7^{p}$ & $4.0^{p}$ & $438-673$ & $573[5]$ & {$[160]$} \\
\hline $\mathrm{Mg}\left(\mathrm{BH}_{4}\right)_{2}=\mathrm{MgB}_{2}+4 \mathrm{H}_{2}$ & $\begin{array}{c}\text { Activated carbon } \\
(<2)\end{array}$ & $44 \pm 3$ & $6.0^{m}$ & & $443-773$ & & [216] \\
\hline $\mathrm{LiBH}_{4}+3.75$ mass $\% \mathrm{Ni}$ & $\begin{array}{c}\text { Nanoporous carbon } \\
(2-3)\end{array}$ & 25 & $14^{p}$ & $10^{p}$ & $473-673$ & $593[4]$ & [220] \\
\hline $\begin{array}{l}\mathrm{LiBH}_{4}+1 / 2 \mathrm{MgH}_{2}=\mathrm{LiH}+ \\
1 / 2 \mathrm{MgB}_{2}+2 \mathrm{H}_{2}\end{array}$ & $\begin{array}{c}\text { Nanoporous carbon aerogel } \\
(\sim 21)\end{array}$ & & $4.7^{m}$ & $4^{m}$ & $533-743$ & $\begin{array}{c}643-663 \\
{[5-10]} \\
\end{array}$ & [221] \\
\hline
\end{tabular}

* represents that the release of $\mathrm{NH}_{3}$ in the decomposition process; ${ }^{m}$ indicates the value referred to the mixture of metal borohydride with side products, while ${ }^{p}$ indicates the value referred to the pure metal borohydride. 


\section{Conclusions}

Metal borohydrides $M\left(\mathrm{BH}_{4}\right)_{n}$ with an extremely high hydrogen density, have been regarded as potential candidates for on-board hydrogen storage. The high reaction temperature and sluggish kinetics, however, decrease their potential for practical applications. In order to overcome these barriers, a number of efforts have been devoted to improving the hydrogen storage properties in both thermodynamic and kinetic areas. The thermodynamic stability of $M\left(\mathrm{BH}_{4}\right)_{n}$ can be predicted and tailored by considering the electronegativity of $M$. The multistep reaction pathway together with the formation of an intermediate compound such as $M\left(\mathrm{~B}_{12} \mathrm{H}_{12}\right)_{n / 2}$, might account for the high reaction temperature and slow kinetics. The suppression of the formation of $M\left(\mathrm{~B}_{12} \mathrm{H}_{12}\right)_{n / 2}$ can be realized by the combination of $M\left(\mathrm{BH}_{4}\right)_{n}$ with other hydrides or metals. This approach changes the reaction pathway, and therefore, improves the hydrogen storage properties in both thermodynamic and kinetic areas. Regarding the improvement of reaction kinetics, both additives and nanoconfinement have been proved to be vital.

None of the current materials can fulfill the requirements of on-board hydrogen storage for fuel cell vehicles; therefore, continued efforts are required to develop novel materials. According to theoretical predications, many $M\left(\mathrm{BH}_{4}\right)_{n}$ have the potential to release hydrogen at a moderate temperature, and the sluggish kinetics are considered to be mainly responsible for the high reaction temperature. Effective strategies to achieve fast reaction kinetics will be an important research direction to achieve practical success with metal borohydrides.

\section{Acknowledgments}

Financial support received from NEDO (New Energy and Industrial Technology Development Organization, in collaboration with Toyota Central R\&D Labs., Inc.); GCOE (Global COE program, Tohoku University); DOE (Department of Energy) and European Commission is greatly appreciated.

\section{References}

1. Schlapbach, L.; Züttel, A. Hydrogen-storage materials for mobile applications. Nature 2001, 414, 353-358.

2. Orimo, S.; Nakamori, Y.; Eliseo, J.; Züttel, A.; Jensen, C.M. Complex Hydrides for Hydrogen Storage. Chem. Rev. 2007, 107, 4111-4132.

3. Nakamori, Y.; Orimo, S. Borohydrides as hydrogen storage materials. In Solid-State Hydrogen Storage; Walker, G., Ed.; Woodhead Publishing Limited: Cambridge, UK, 2008; pp. 420-449.

4. Miwa, K.; Ohba, N.; Towata, S.; Nakamori, Y.; Orimo, S. First-principles Study on Lithium Borohydride $\mathrm{LiBH}_{4}$. Phys. Rev. B 2004, 69, 245120.

5. Ge, Q. Structure and Energetics of $\mathrm{LiBH}_{4}$ and Its surfaces: A First-Principles Study. J. Phys. Chem. A 2004, 108, 8682-8690.

6. Vajeeston, P.; Ravindran, P.; Kjekshus, A.; Fjellvåg. Structrual Stability of Alkali Boron Tetrahydrides $\mathrm{ABH}_{4}(\mathrm{~A}=\mathrm{Li}, \mathrm{Na}, \mathrm{K}, \mathrm{Rb}, \mathrm{Cs})$ From First Principle Calculation. J. Alloys Compd. 2005, 387, 97-104. 
7. Lodziana, Z.; Vegge, T. Structural Stability of Complex Hydrides: $\mathrm{LiBH}_{4}$ Revisited. Phys. Rev. Lett. 2004, 93, 14550.

8. Orgaz, E.; Membrillo, A.; Castañeda, R.; Aburto, A. Electronic Structure of Ternary Hydrides Based on Light Elements. J. Alloys Compd. 2005, 404-406, 176-180.

9. Schlesinger, H.I.; Brown, H.C.; Finholt, A.E.; Gilbreath, J.R.; Hoekstra, H.R.; Hyde, E.K. Sodium Borohydride, Its Hydrolysis and its Use as a Reducing Agent and in the Generation of Hydrogen. J. Am. Chem. Soc. 1953, 75, 215-219.

10. Liu, B.H.; Li, Z.P.; Suda, S. Nickel- and cobalt-based catalysts for hydrogen generation by hydrolysis of borohydride. J. Alloys Compd. 2006, 415, 288-293.

11. Wang, P.; Kang, X.D. Hydrogen-rich boron-containing materials for hydrogen storage. Dalton Trans. 2008, 40, 5400-5413.

12. Grochala, W.; Edwards, P.P. Thermal Decomposition of the Non-Interstitial Hydrides for the Storage and Production of Hydrogen. Chem. Rev. 2004, 104, 1283-1315.

13. Sakintuna, B.; Lamari-Darkrimb, F.; Hirscherc, M. Metal Hydride Materials for Solid Hydrogen Storage: A review. Int. J. Hydrogen Energy 2007, 32, 1121-1140.

14. Chen, P.; Zhu, M. Recent progress in hydrogen storage. Mater. Today. 2008, 11, 36-43.

15. Rönnebro, E. Development of group II borohydrides as hydrogen storage materials. Curr. Opin. Solid State Mater. Sci. 2010, doi:10.1016/j.cossms.2010.10.003.

16. George, L.; Saxena, S.K. Structural Stability of Metal Hydrides, Alanates and Borohydrides of Alkali and Alkali-Earth Elements: A Review. Int. J. Hydrogen Energy 2010, 35, 5454-5470.

17. Jain, I.P.; Jain P.; Jain, A. Novel hydrogen storage materials: A review of lightweight complex hydrides. J. Alloys Compd. 2010, 503, 303-339.

18. Hagemann H.; Černý, R. Synthetic approaches to inorganic borohydrides. Dalton Trans. 2010, 39, 6006-6012.

19. Züttel, A.; Wenger, P.; Rentsch, S.; Sudan, P. $\mathrm{LiBH}_{4}$ A New Hydrogen Storage Material. J. Power Sources 2003, 118, 1-7.

20. Züttel, A.; Rentsch, S.; Fischer, P.; Wenger, P.; Sudan, P.; Mauron, Ph.; Emmenegger, Ch. Hydrogen Storage Properties of $\mathrm{LiBH}_{4}$. J. Alloys Compd. 2003, 356-357, 515-520.

21. Nakamori, Y.; Orimo, S. Destabilization of Li-based Complex Hydrides. J. Alloys Compd. 2004, 370, 271-275.

22. Orimo, S.; Nakamor, Y.; Züttel, A. Material Properties of $\mathrm{MBH}_{4}(\mathrm{M}=\mathrm{Li}, \mathrm{Na}$, and K). Mater. Sci. Eng. B 2004, 108, 51-53.

23. Orimo, S.; Nakamori, Y.; Kitahara, G.; Miwa, K.; Ohba, N.; Towata, S.; Züttel, A. Dehydriding and Rehydriding Reactions of $\mathrm{LiBH}_{4}$. J. Alloys Compd. 2005, 404-406,427-430.

24. Nakamori, Y.; Orimo, S.; Tsutaoka, T. Dehydriding Reaction of Metal Hydrides and Alkali Borohydrides Enhanced by Microwave Irradiation. Appl. Phys. Lett. 2006, 88, 112104.

25. Züttel, A.; Borgschulte, A.; Orimo, S. Tetrahydroborates as New Hydrogen Storage Materials. Scripta Mater. 2007, 56, 823-828.

26. Orimo, S.; Nakamori, Y.; Ohba, N.; Miwa, K.; Aoki, M.; Miwa, S.; Züttel, A. Experimental Studies on Intermediate Compound of $\mathrm{LiBH}_{4}$. Appl. Phys. Lett. 2006, 89, 021920. 
27. Ohba, N.; Miwa, K.; Aoki, M.; Noritake, T.; Towata, S.; Nakamori, Y.; Orimo, S.; Züttel, A. First-Principles Study on the Stability of Intermediate Compounds of $\mathrm{LiBH}_{4}$. Phys. Rev. B 2006, 74, 075110.

28. Hwang, S.-J.; Bowman, R.C., Jr.; Reiter, J.W.; Rijssenbeek, J.; Soloverchik, G.L.; Zhao, J.-C.; Kabbour, H.; Ahn, C.C. NMR Confirmation for Formation of $\left[\mathrm{B}_{12} \mathrm{H}_{12}\right]^{2-}$ Complexes during Hydrogen Desorption from Metal Borohydrides. J. Phys. Chem. C 2008, 112, 3164-3169.

29. Ozolin, V.; Majzoub, E.H.; Wolverton, C. First-Principles Predition of Thermodynamically Reversible Hydrogen Storage Reactions in the Li-Mg-Ca-B-H. System. J. Am. Chem. Soc. 2009, 131, 230-237.

30. Her, J.-H.; Yousufuddin, M.; Zhou, W.; Jalisatgi, S.S.; Kulleck, J.G.; Zan, J.A.; Hwang, S.-J.; Bowman, R.C., Jr.; Udovic, T.J. Crystal Structure of $\mathrm{Li}_{2} \mathrm{~B}_{12} \mathrm{H}_{12}$ : A Possible Intermediate Phase in the Decomposition of $\mathrm{LiBH}_{4}$. Inorg. Chem. 2008, 47, 9757-9759.

31. Friedrichs, O.; Remhof, A.; Hwang, S.-J.; Züttel, A. Role of $\mathrm{Li}_{2} \mathrm{~B}_{12} \mathrm{H}_{12}$ for the Formation and Decomposition of $\mathrm{LiBH}_{4}$. Chem. Mater. 2009, 22, 3265-3268.

32. Soulié, J-Ph.; Renaudin, G.; Černy, R; Yvon, K. Lithium Boro-hydride $\mathrm{LiBH}_{4}$. I. Crystal Structure. J. Alloys Compd. 2002, 346, 200-205.

33. Renaudin, G.; Gomes, S.; Hagemann, H.; Keller, L.; Yvon, K. Structural and Spectroscopic Studies on the Alkali Borohydrides $\mathrm{MBH}_{4}(\mathrm{M}=\mathrm{Na}, \mathrm{K}, \mathrm{Rb}, \mathrm{Cs})$. J. Alloys Compd. 2004, 375, 98-106.

34. Frankcombe, T.J.; Kroes, G.-J. Quasiharmonic Approximation Applied to $\mathrm{LiBH}_{4}$ and Its Decomposition Products. Phys. Rev. B 2006, 73, 174302.

35. Hartman, M.R.; Rush, J.J.; Udovic, T.J.; Bowman, R.C., Jr.; Hwang, S.-J. Structure and Vibrational Dynamics of Isotopically Labeled Lithium Borohydride Using Neutron Diffraction and Spectroscopy. J. Solid State Chem. 2007, 180, 1298-1305.

36. Łodziana, Z.; Züttel, A.; Zielinski, P. Titanium and Native Defects in $\mathrm{LiBH}_{4}$ and $\mathrm{NaAlH}_{4}$. J. Phys: Condens. Matter. 2008, 20, 465210.

37. Borgschulte, A.; Züttel, A.; Hug, P.; Racu, A.-M.; Schoenes, J. Hydrogen-Deuterium Exchange in Bulk LiBH 4 . J. Phys. Chem. A 2008, 112, 4749-4753.

38. Buchter, F.; Łodziana, Z.; Mauron, Ph.; Remhof, A.; Friedrichs, Q.; Borgschulte, A.; Züttel, A.; Sheptyakov, D.; Strässle, Th.; Ramirez-Cuesta, A.J. Dynamical Properties and Temperature Induced Molecular Disordering of $\mathrm{LiBH}_{4}$ and $\mathrm{LiBD}_{4}$. Phys. Rev. B 2008, 78, 094302.

39. Skripov, A.V.; Soloninin, A.V.; Filinchuk, Y.; Chernyshov, D. Nuclear Magnetic Resonance Study of Rotational Motion and The Phase transition in $\mathrm{LiBH}_{4}$. J. Phys. Chem. C 2008, 112, 18701-18705.

40. Corey, R.L.; Shane, D.T.; Bowman, R.C., Jr.; Conradi, M.S. Atomic Motions in $\mathrm{LiBH}_{4}$ by NMR. J. Phys. Chem. C 2008, 112, 18706-18710.

41. Gremaud, R.; Łodziana, Z.; Hug, P.; Willenberg, B.; Racu, A.-M.; Schoenes, J.; Ramirez-Cuesta, A.J.; Clark, S.J.; Refson, K.; Züttel, A.; Borgschulte, A. Evidence for Hydrogen Transport in Deuterated $\mathrm{LiBH}_{4}$ from Low-Temperature Raman-Scattering Measurement and First-Principles Calculations. Phys. Rev. B 2008, 80, 100301.

42. Filinchuk, Y.; Chernyshov, D.; Nevidomskyy, A.; Dmitriev, V. High-Pressure Polymorphism as a Step towards Destabilization of $\mathrm{LiBH}_{4}$. Angew. Chem. Int. Ed. 2008, 47, 529-532. 
43. Shane, D.T.; Bowman, R.C., Jr.; Conradi, M.S. Exchange of Hydrogen Atoms between $\mathrm{BH}_{4}$ in $\mathrm{LiBH}_{4}$. J. Phys. Chem. C 2009, 113, 5039-5042.

44. Ramzan, M.; Ahuja, R. Ab initio Molecular Dynamics Study of the Hydrogen-Deuterium Exchange in Bulk Lithiumborohydride ( $\left.\mathrm{LiBH}_{4}\right)$. Appl. Phys. Lett. 2009, 94, 141903.

45. Hagemann, H.; Filinchuk, Y.; Chernyshov, D.; van Beek, W. Lattice Anharmonicity and Structural Evolution of $\mathrm{LiBH}_{4}$ : an Insight from Raman and X-ray Diffraction Experiments. Phase Transitions 2009, 82, 344-355.

46. Andresen, E.R.; Gremaud, R.; Borgschulte, A.; Ramirez-Cuesta, A.J.; Züttel, A.; Hamm, P. Vibrational Dynamics of $\mathrm{LiBH}_{4}$ by Infrared Pump-Probe and 2D Spectroscopy. J. Phys. Chem. A 2009, 113, 12838-12846.

47. Hao, S.; Sholl, D.S. The Role of Interstitial $\mathrm{H}_{2}$ in Hydrogen Diffusion in Light Metal Borohydrides. Phys. Chem. Chem. Phys. 2009, 11, 11106-11109.

48. Galvez-Ruiz, J.C.; Sanchez, M. Structural Analysis of Alkali Metal Tetrahydroborates: The Role of Metal and Coordination from in the $\left[\mathrm{BH}_{4}\right]^{-}$Anion Structure. J. Mol. Struc.: Theochem. 2009, 908, 114-116.

49. Remhof, A.; Gremaud, R.; Buchter, F.; Lodziana, Z.; Embs, J.P.; Ramirez-Cuesta, A.J.; Borgschulte, A.; Züttel, A. Hydrogen Dynamics in Lightweight Tetrahydroborates. Z. Phys. Chem. 2010, 224, 263-278.

50. Remhof, A.; Lodziana, Z.; Martelli, P.; Friedrichs, O.; Züttel, A.; Skripov, A.V.; Embs, J.P.; Strässle, T. Rotational Motion of $\mathrm{BH}_{4}$ Units in $\mathrm{MBH}_{4}(\mathrm{M}=\mathrm{Li}, \mathrm{Na}, \mathrm{K})$ from Quasielastic Neutron Scattering and Density Functional Calculations. Phys. Rev. B 2010, 81, 214304.

51. Mauron, P.; Buchter, F.; Friedrichs, O.; Remhof, A.; Bielmann, M.; Zwichy, C.N.; Züttel, A. Stability and Reversibility of $\mathrm{LiBH}_{4}$. J. Phys. Chem. B 2008, 112, 906-910.

52. Friedrichs, O.; Buchter, F.; Borgschulte, A.; Remhof, A.; Zwicky, C.N.; Mauron, P.H.; Bielmann, M.; Züttel, A. Direct Synthesis of $\mathrm{Li}\left[\mathrm{BH}_{4}\right]$ and $\mathrm{Li}\left[\mathrm{BD}_{4}\right]$ from the Elements. Acta Mater. 2007, 56, 949-954.

53. Remhof, A.; Friedrichs, O.; Buchter, F.; Mauron, P.H.; Züttel, A.; Wallacher, D. Solid-State Synthesis of $\mathrm{LiBD}_{4}$ Observed by In Situ Neutron Diffraction. Phys. Chem. Chem. Phys. 2008, 10, 5859-5862.

54. Friedrichs, O.; Borgschulte, A.; Kato, S.; Buchter, F.; Gremaud, R.; Remhof, A.; Züttel, A. LowTemperature Synthesis of $\mathrm{LiBH}_{4}$ by Gas-Solid Reaction. Chem. Eur. J. 2009, 15, 5531-5534.

55. Friedrichs, O.; Remhof, A.; Borgschulte, A.; Buchter, F.; Orimo, S.; Züttel, A. Breaking the passivation - the road to a solvent fee borohydride synthesis. Phys. Chem. Chem. Phys. 2010, 12, 10919-10922.

56. Matsunaga, T.; Buchter, F.; Mauron, P.; Bielman, M.; Nakamori, Y.; Orimo, S.; Ohba, N.; Miwa, K.; Towata, S.; Züttel, A. Hydrogen Storage Properties of $\operatorname{Mg}\left(\mathrm{BH}_{4}\right)_{2}$. J. Alloys Compd. 2008, 459, 583-588.

57. Chłopek, K.; Frommen, C.; Léon, A.; Zabara, O.; Fichtner, M. Synthesis and Properties of Magnesium Tetrahydroborate, $\mathrm{Mg}\left(\mathrm{BH}_{4}\right)_{2}$. J. Mater. Chem. 2007, 17, 3496-3503.

58. Li, H.-W.; Kikuchi, K.; Nakamori, Y.; Miwa, K.; Towata, S.; Orimo, S. Effects of Ball Milling and Additives on Dehydriding Behaviors of Well-crystallized $\mathrm{Mg}\left(\mathrm{BH}_{4}\right)_{2}$. Scripta Mater. 2007, 57, 679-682. 
59. Riktor, M.D.; Sørby, M.H.; Chłopek, K.; Fichtner, M.; Buchter, F.; Züttel, A.; Hauback, B.C. In Situ Synchrotron Diffraction Studies of Phase Transitions and Thermal Decomposition of $\mathrm{Mg}\left(\mathrm{BH}_{4}\right)_{2}$ and $\mathrm{Ca}\left(\mathrm{BH}_{4}\right)_{2}$. J. Mater. Chem. 2007, 17, 4939-4942.

60. Matsunaga, T.; Buchter, F.; Miwa, K.; Towata, S.; Orimo, S.; Züttel, A. Magnesium borohydride: A New Hydrogen Storage Material. Renew. Energy 2008, 33, 193-196.

61. Varin, R.A.; Chiu, Ch.; Wronski, Z.S. Mechano-Chemical Activation Synthesis (MCAS) of Disordered $\mathrm{Mg}\left(\mathrm{BH}_{4}\right)_{2}$ Using $\mathrm{NaBH}_{4}$. J. Alloys Compd. 2008, 462, 201-208.

62. Li, H.-W.; Kikuchi, K.; Nakamori, Y.; Ohba, N.; Miwa, K.; Towata, S.; Orimo, S. Dehydriding and Rehydriding Processes of Well-Crystallized $\mathrm{Mg}\left(\mathrm{BH}_{4}\right)_{2}$ Accompanying with Formation of Intermediate Compounds. Acta Mater. 2008, 56, 1342-1347.

63. Hanada, N.; Chlopek, K.; Frommen, C.; Lohstroh, W.; Fichtner, M. Thermal Decomposition of $\mathrm{Mg}\left(\mathrm{BH}_{4}\right)_{2}$ Under He flow and $\mathrm{H}_{2}$ Pressure. J. Mater. Chem. 2008, 18, 2611-2614.

64. Yan, Y.; Li, H.-W.; Nakamori, Y.; Ohba, N.; Miwa, K.; Towata, S.; Orimo, S. Differential Scanning Calorimetry Measurements of Magnesium Borohydride $\mathrm{Mg}\left(\mathrm{BH}_{4}\right)_{2}$. Mater. Trans. 2008, 49, 2751-2752.

65. Soloveichika, G.L.; Gao, Y.; Rijssenbeek, J.; Andrus, M.; Kniajanski, S.; Bowman, R.C., Jr.; Hwangc, S.-J.; Zhao, J.-C. Magnesium Borohydride as a Hydrogen Storage Material: Properties and Dehydrogenation Pathway of Unsolvated $\mathrm{Mg}\left(\mathrm{BH}_{4}\right)_{2}$. Int. J. Hydrogen Energy 2009, 34, 916-928.

66. Li, H.-W.; Miwa, K.; Ohba, N.; Fujita, T.; Sato, T.; Yan, Y.; Towata, S.; Chen, M.W.; Orimo, S. Formation of Intermediate Compound with $\mathrm{B}_{12} \mathrm{H}_{12}$ Cluster: Experimental and Theoretical Studies on Magnesium Borohydride $\mathrm{Mg}\left(\mathrm{BH}_{4}\right)_{2}$. Nanotechnology 2009, 20, 204013.

67. Ozolins, V.; Majzoub, E.H.; Wolverton, C. First-Principles Prediction of a Ground State Crystal Structure of Magnesium Borohydride. Phys. Rev. Lett. 2008, 100, 135501.

68. van Setten, M.J.; Lohstroh, W.; Fichtner, M. A New Phase in the Decomposition of $\operatorname{Mg}\left(\mathrm{BH}_{4}\right)_{2}$ : First-Principles Simulated Annealing. J. Mater. Chem. 2009, 19, 7081-7087.

69. Kulkarni, A.D.; Wang, L.L.; Johnson, D.D.; Sholl, D.S.; Johnson, J.K. First-principles Characterization of Amorphous Phases of $\mathrm{MB}_{12} \mathrm{H}_{12}, \mathrm{M}=\mathrm{Mg}$, Ca. J. Phys. Chem. C 2010, 114, 14601-14605.

70. Li, S.; Willis, M.; Jena, P. Reaction Intermediates during the Dehydrogenation of Metal Borohydrides: A Cluster Perspective. J. Phys. Chem. C 2010, 114, 16849-16854.

71. Chen, X.; Lingam, H.K.; Huang, Z.; Yisgedu, T.; Zhao, J.-C.; Shore, S.G. Thermal Decomposition Behavior of Hydrated Magnesium Dodecahydrododecaborates. J. Phys. Chem. Lett. 2010, 1, 201-204.

72. Newhouse, R.J.; Stavila, V.; Hwang, S.-J.; Klebanoff, L.E.; Zhang, J.Z. Reversibility and Improved Hydrogen Release of Magnesium Borohydride. J. Phys. Chem. C 2010, 114, 5224-5232.

73. Severa, G.; Rönnebro, E.; Jensen, C.M. Direct Hydrogenation of Magnesium Boride to Magnesium Borohydride: Demonstration of $>11$ Weight Percent Reversible Hydrogen Storage. Chem. Commun. 2010, 46, 421-423.

74. Li, H.-W.; Matsunaga, T.; Yan, Y.; Maekawa, H.; Ishikiriyama, M.; Orimo, S. Nanostructureinduced hydrogenation of layered compound $\mathrm{MgB}_{2}$. J. Alloys Compd. 2010, 505, 654-656. 
75. Pistidda, C.; Garroni, S.; Dolci, F.; Bardají, E.G.; Khandelwal, A.; Nolis, P.; Dornheim, M.; Gosalawit, R.; Jensen, T.; Cerenius, Y.; Suriñach, S.; Baró, M.D.; Lohstroh, W.; Fichtner, M. Synthesis of amorphous $\mathrm{Mg}\left(\mathrm{BH}_{4}\right)_{2}$ from $\mathrm{MgB}_{2}$ and $\mathrm{H}_{2}$ at room temperature. J. Alloys Compd. 2010, 508, 212-215.

76. Chong, M.; Karkamkar, A.; Autrey, T.; Orimo, S.; Jalisatgi, S.; Jensen, C.M. Reversible dehydrogenation of magnesium borohydride to magnesium triborane in the solid state under moderate conditions. Chem. Commun. 2011, 47, 1330-1332.

77. Miwa, K.; Aoki, M.; Noritake, T.; Ohba, N.; Nakamori, Y.; Towata, S.; Züttel, A.; Orimo, S. Thermodynamical Stability of Calcium Borohydride $\mathrm{Ca}\left(\mathrm{BH}_{4}\right)_{2}$. Phys. Rev. B 2006, 74, 155122.

78. Kim, J.-H.; Jin, S.-A.; Shim, J.-H.; Cho, Y.W. Thermal Decomposition Behavior of Calcium Borohydride $\mathrm{Ca}\left(\mathrm{BH}_{4}\right)_{2}$. J. Alloys Compd. 2008, 461, L20-L22.

79. Aoki, M.; Miwa, K.; Noritake, T.; Ohba, N.; Matsumoto, M.; Li, H.-W.; Nakamori, Y.; Towata, S.; Orimo, S. Structural and Dehydriding Properties of $\mathrm{Ca}\left(\mathrm{BH}_{4}\right)_{2}$. Appl. Phys. A 2008, 92, 601-605.

80. Mao, J.; Guo, Z.; Poh, C.K.; Ranjbar, A.; Guo, Y.; Yu, X.; Liu, H. Study on the dehydrogenation kinetics and thermodynamics of $\mathrm{Ca}\left(\mathrm{BH}_{4}\right)_{2}$. J. Alloys Compd. 2010, 500, 200-205.

81. Riktor, M.D.; Sørby, M.H.; Chopek, K.; Fichtner, M.; Haubac, B.C.; The Identification of a Hitherto Unknown Intermediate Phase $\mathrm{CaB}_{2} \mathrm{H}_{\mathrm{X}}$ from Decomposition of $\mathrm{Ca}\left(\mathrm{BH}_{4}\right)_{2}$. J. Mater. Chem. 2009, 19, 2754-2759.

82. Frankcombe, T.J. Calcium Borohydride for Hydrogen Storage: A Computational Study of $\mathrm{Ca}\left(\mathrm{BH}_{4}\right)_{2}$ Crystal Structures and the $\mathrm{CaB}_{2} \mathrm{H}_{x}$ Intermediate. J. Phys. Chem. C 2010, 114, 9503-9509.

83. Wang, L.-L.; Graham, D.D.; Robertson, I.M.; Johnson, D.D. On the Reversibility of HydrogenStorage Reactions in $\mathrm{Ca}\left(\mathrm{BH}_{4}\right)_{2}$ : Characterization via Experiment and Theory. J. Phys. Chem. C 2009, 113, 20088-20096.

84. Stavila, V.; Her, J.-H.; Zhou, W.; Hwang, S.-J., Kim, C.; Ottley, L.A.M.; Udovic, T.J. Probing the structure, stability and hydrogen storage properties of calcium dodecahydro-closododecaborate. J. Solid State Chem. 2010, 183, 1133-1140.

85. Rönnebro, E.; Majzoub, E.H. Calcium Borohydride for Hydrogen Storage: Catalysis and Reversibility. J. Phys. Chem. B 2007, 111, 12045-12047.

86. Kim, J.-H.; Jin, S.-A.; Shim, J.-H.; Cho, Y.W. Reversible Hydrogen Storage in Calcium Borohydride $\mathrm{Ca}\left(\mathrm{BH}_{4}\right)_{2}$. Scripta Mater. 2008, 58, 481-483.

87. Kim, J.-H.; Shim, J.-H.; Cho, Y.W. On the Reversibility of Hydrogen Storage in Ti- and $\mathrm{Nb}$-catalyzed $\mathrm{Ca}\left(\mathrm{BH}_{4}\right)_{2}$. J. Power Sources. 2008, 181, 140-143.

88. Sato, T.; Miwa, K.; Nakamori, Y.; Ohoyama, K.; Li, H.-W.; Noritake, T.; Aoki, M.; Towata, S.; Orimo, S. Experimental and computational studies on solvent-free rare-earth metal borohydrides $\mathrm{R}\left(\mathrm{BH}_{4}\right)_{3}(\mathrm{R}=\mathrm{Y}, \mathrm{Dy}$, and Gd). Phys. Rev. B 2008, 77, 104114.

89. Yan, Y.; Li, H.-W.; Sato, T.; Umeda, N.; Miwa, K.; Towata, S.; Orimo, S. Dehydriding and rehydriding properties of yttrium borohydride $\mathrm{Y}\left(\mathrm{BH}_{4}\right)_{3}$ prepared by liquid-phase synthesis. Int. J. Hydrogen Energy 2009, 34, 5732-5736. 
90. Frommen, C.; Aliouane, N.; Deledda, S.; Fonnelop, J.E.; Grove, H.; Lieutenant, K.; Llamas-Jansa, I.; Sartori, S.; Sorby, M.H.; Hauback, B.C. Crystal structure, polymorphism, and thermal properties of yttrium borohydride $\mathrm{Y}\left(\mathrm{BH}_{4}\right)_{3}$. J. Alloys Compd. 2010, 496, 710-716.

91. Ravnsbæk, D.B.; Filinchuk, Y.; Cerny, Radovan.; Ley, M.B.; Haase, D.; Jakobsen, H.J.;

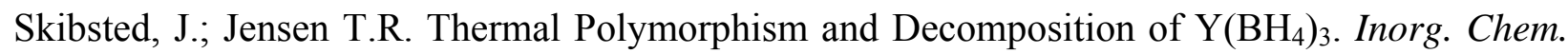
2010, 49, 3801-3809.

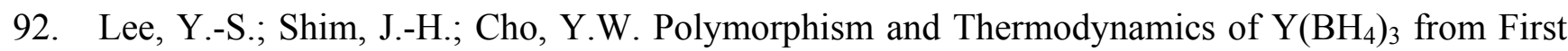
Principles. J. Phys. Chem. C 2010, 114, 12833-12837.

93. Jaroń, T.; Grochala, W. $\mathrm{Y}\left(\mathrm{BH}_{4}\right)_{3}$-an Old-New Ternary Hydrogen Store aka Learning from a Multitude of Failures. Dalton Trans. 2010, 39, 160-166.

94. Gennari, F.C.; Esquivel, M.R. Synthesis and Dehydriding Process of Crystalline $\mathrm{Ce}\left(\mathrm{BH}_{4}\right)_{3}$. J. Alloys Compd. 2009, 485, L47-L51.

95. Jeon, E.; Cho, Y.W. Mechanochmical Synthesis and Thermal Decomposition of Zinc Borohydride. J. Alloys Compd. 2006, 422, 273-275.

96. Srinivasan, S.; Escobar, D.; Jurczyk, M.; Goswami, Y.; Stefanakos, E. Nanocatalyst Doping of $\mathrm{Zn}\left(\mathrm{BH}_{4}\right)_{2}$. J. Alloys. Compd. 2008, 462, 294-302.

97. Titov, L.V.; Eremin, E.R. Complex of Aluminum Borohydride with Calcium Borohydride. Russ. Chem. B.1975, 24, 1095-1096.

98. Fang, Z.Z.; Ma, L.P.; Kang, X.D.; Wang, P.J.; Wang, P.; Cheng, H.M. In situ Formation and Rapid Decomposition of $\mathrm{Ti}\left(\mathrm{BH}_{4}\right)_{3}$ by Mechanical Milling $\mathrm{LiBH}_{4}$ with $\mathrm{TiF}_{3}$. Appl. Phys. Lett. 2009, 94, 044104.

99. Gennari, F.C.; Albanesi, L.F.; Rios, I.J. Synthesis and Thermal Stability of $\mathrm{Zr}\left(\mathrm{BH}_{4}\right)_{4}$ and $\mathrm{Zr}\left(\mathrm{BD}_{4}\right)_{4}$ Produced by Mechanochemical Processing. Inorg. Chim. Acta. 2009, 362, 3731-3737.

100. Łodziana, Z. Multivalent metal tetrahydroborides of Al, Sc, Y, Ti, and Zr. Phy. Rev. B 2010, 81, 144108.

101. Choudhury, P.; Srinivasan, S.S; Bhethanabotla, V.R.; Goswami, Y.; McGrath, K.; Stefanakos, E.K. Nano-Ni Doped Li-Mn-B-H System as a New Hydrogen Storage Candidate. Int. J. Hydrogen Energy. 2009, 34, 6325-6334.

102. Varin, R.A.; Zbroniec, L. The Effects of Ball Milling Nanometric Nickel on the Hydrogen Desorption from Lithium Borohydride and Manganese Chloride (3 $\left.\mathrm{LiBH}_{4}+\mathrm{MnCl}_{2}\right)$ Mixture. Int. J. Hydrogen Energy. 2010, 35, 3588-3597.

103. Černý, R.; Penin, N.; Hagemann, H.; Filinchuk Y. The First Crystallographic and Spectroscopic Characterization of a 3d-Metal Borohydride: $\mathrm{Mn}\left(\mathrm{BH}_{4}\right)_{2}$. J. Phys. Chem. C 2009, 113, 9003-9007.

104. Nakamori, Y.; Miwa, K.; Ninoyiya, A.; Li, H.; Ohba, N.; Towata, S.; Züttel, A.; Orimo, S. Correlation between Thermodynamical Stabilities of Metal Borohydrides and Cation Electronegativities: First-Principles Calculations and Experiments. Phys. Rev. B 2006, 74, 045126.

105. Nakamori, Y.; Li, H.-W.; Mastuo, M.; Miwa, K.; Towata, S.; Orimo, S. Development of Metal Borohydrides for Hydrogen Storage. J. Phys. Chem. Sol. 2008, 69, 2292-2296.

106. Sugiyama, J.; Ikedo, Y.; Noritake, T.; Ofer, O.; Goko, T.; Månsson, M.; Miwa, K.; Ansaldo, E.J.; Brewer, J.H.; Chow, K.H.; Towata, S. Microscopic Indicator for Thermodynamic Stability of 
Hydrogen Storage Materials Provided by Positive Muon-Spin Rotation. Phys. Rev. B 2010, 81, 092103.

107. Li, H.-W.; Orimo, S.; Nakamori, Y.; Miwa, K.; Ohba, N. Towata, S.; Züttel, A. Materials Designing of Metal Borohydrides: Viewpoints from Thermodynamically Stabilities. J. Alloys Compd. 2007, 446-447, 315-318.

108. Nickels, E.A.; Jones, M.O.; David, W.I.F.; Johnson, S.R.; Lowton, R.L.; Sommariva, M.; Edwards, P.P. Tuning the Decomposition Temperature in Complex Hydrides: Synthesis of a Mixed Alkali Metal Borohydride. Angew. Chem. Int. Ed. 2008, 47, 2817-2819.

109. Hagemann, H.; Longhini, M.; Kaminski, J.W.; Wesolowski, T.A.; Černy, R.; Penin, N.; Sørby, M.H.; Hauback, B.C.; Severa, G.; Jensen, C.M. LiSc $\left(\mathrm{BH}_{4}\right)_{4}$ : A Novel Salt of $\mathrm{Li}^{+}$and Discrete $\mathrm{Sc}\left(\mathrm{BH}_{4}\right)_{4}{ }^{-}$Complex Anions. J. Phys. Chem. A 2008, 112, 7551-7555.

110. Seballos, J.; Zhang, J.Z.; Rönnebro, E.; Herberg, J.L.; Majzoub, E.H. Metastabilility and Crystal Structure of the Bialkali Complex Metal Borohydride $\mathrm{NaK}\left(\mathrm{BH}_{4}\right)_{2}$. J. Alloys Compd. 2009, 476, $446-450$.

111. Kim, C.; Hwang, S.-J.; Bowman, R.C., Jr.; Reiter, J.W.; Zan, J.A.; Kulleck, J.G.; Kabbour, H.; Majzoub, E.H.; Ozolins, V. $\mathrm{LiSc}\left(\mathrm{BH}_{4}\right)_{4}$ as a Hydrogen Storage Material: Multinuclear High-Resolution Solid-State NMR and First-Principles Density Functional Theory Studies. J. Phys. Chem. C 2009, 113, 9956-9968.

112. Ravnsbæk, D.; Filinchuk, Y.; Cerenius, Y.; Jakobsen, H.J.; Besenbacher, F.; Skibsted, J.; Jensen, T.R. A Series of Mixed-Metal Borohydrides. Angew. Chem. Int. End. 2009, 48, 6659-6663.

113. Černý, R.; Severa, G.; Ravnsbæk, D.B.; Filinchuk, Y.; D’Anna, V.; Hagemann, H.; Haase, D.; Jensen, C.M.; Jensen, T.R. NaSc $\left(\mathrm{BH}_{4}\right)_{4}$ : A Novel Scandium-Based Borohydride. J. Phys. Chem. C 2010, 114, 1357-1364.

114. Severa, G.; Hagemann, H.; Longhini, M.; Kaminski, J.W.; Wesolowski, T.A.; Jensen, C.M. Thermal Desorption, Vibrational Spectroscopic, and DFT Computational Studies of the Complex Manganese Borohydrides $\mathrm{Mn}\left(\mathrm{BH}_{4}\right)_{2}$ and $\left[\mathrm{Mn}\left(\mathrm{BH}_{4}\right)_{4}\right]^{2-}$. J. Phys. Chem. C 2010, 114, 15516-15521.

115. Fang, Z.Z.; Kang, X.D.; Wang, P.; Li, H.-W.; Orimo, S. Unexpected Dehydrogenation Behavior of $\mathrm{LiBH}_{4} / \mathrm{Mg}\left(\mathrm{BH}_{4}\right)_{2}$ Mixture Associated with the In Situ Formation of Dual-Cation Borohydride. J. Alloys Compd. 2010, 491, L1-L4.

116. Lee, J.Y.; Ravnsbæk, D.; Lee, Y.-S.; Kim, Y.; Cerenius, Y.; Shim, J.-H.; Jensen, T.R.; Hur, N.H.; Cho, Y.W. Decomposition Reactions and Reversibility of the $\mathrm{LiBH}_{4}-\mathrm{Ca}\left(\mathrm{BH}_{4}\right)_{2}$ Composite. J. Phys. Chem. C 2009, 113, 15080-15086.

117. Černý, R.; Ravnsbæk, D.B.; Severa G.; Filinchuk Y.; D’Anna, V.; Hagemann, H.; Haase, D.; Skibsted J.; Jensen, C.M.; Jensen, T.R. Structure and Characterization of $\mathrm{KSc}\left(\mathrm{BH}_{4}\right)_{4}$. J. Phys. Chem. C 2010, 114, 19540-19549.

118. Vajo, J.J.; Olson, G.L. Hydrogen Storage in Destabilized Chemical Systems. Scripta Mater. 2007, 56, 829-834.

119. NIST Webbook. Available online: http://webbook.nist.gov/chemistry (accessed on 12 January 2011).

120. Vajo, J.J.; Skeith, S.L.; Mertens, F. Reversible Storage of Hydrogen in Destabilized $\mathrm{LiBH}_{4}$. J. Phys. Chem. B 2005, 109, 3719-3722. 
121. Aoki, M.; Miwa, K.; Noritake, T.; Kitahara, G.; Nakamori, Y.; Orimo, S.; Towata, S. Destabilization of $\mathrm{LiBH}_{4}$ by Mixing with $\mathrm{LiNH}_{2}$. Appl. Phys. A 2005, 80, 1409-1412.

122. Johnson, S.R.; Anderson, P.A.; Edwards, P.P.; Gameson, I.; Prendergast, J.W.; Al-Mamouri, M.; Book, D.; Harris, I.R.; Speight, J.D.; Walton, A. Chemical Activation of $\mathrm{MgH}_{2}$, a New route to Superior Hydrogen Storage Materials. Chem. Commun. 2005, 22, 2823-2825.

123. Pinkerton, F.E.; Meisner, G.P.; Meyer, M.S.; Balogh, M.P.; Kundrat, M.D. Hydrogen Desorption Exceeding Ten Weight Percent from the New Quaternary Hydride $\mathrm{Li}_{3} \mathrm{BN}_{2} \mathrm{H}_{8}$. J. Phys. Chem. B 2005, 109, 6-8.

124. Alapati, S.V.; Johnson, J.K.; Sholl, D.S. Identification of Destabilized Metal Hydrides for Hydrogen Storage Using First Principles Calculations. J. Phys. Chem. B 2006, 110, 8769-8776.

125. Cho, Y.W.; Shim, J.-H.; Lee, B.-J. Thermal Destabilization of Binary and Complex Metal Hydrides by Chemical Reaction: A Thermodynamic Analysis. Comput. Coupling Phase Diagr. Thermochem. 2006, 30, 65-59.

126. Yu, X.B.; Grant, D.M.; Walker, G.S. A New Dehydrogenation Mechanism for Reversible Multicomponent Borohydride Systems - the Role of Li-Mg Alloys. Chem. Commun. 2006, 37, 3906-3908.

127. Nakamori, Y.; Ninomiya, A.; Kitahara, G.; Aoki, M.; Noritake, T.; Miwa, K.; Kojima, Y.; Orimo, S. Dehydriding Reactions of Mixed Complex Hydrides. J. Power Sources. 2006, 155, 447-455.

128. Meisner, G.P.; Scullin, M.L.; Balogh, M.P.; Pinkerton, F.E.; Meyer, M.S. Hydrogen Release from Mixtures of Lithium Borohydride and Lithium Amide: A Phase Diagram Study. J. Phys. Chem. B 2006, 110, 4189-4192.

129. Noritake, T.; Aoki, M.; Towata, S.; Ninimiya, A.; Nakamori, Y.; Orimo, S. Crystal Structure Analysis of Novel Complex Hydrides Formed by Combination of $\mathrm{LiBH}_{4}$ an $\mathrm{LiNH}_{2}$. Appl. Phys. A 2006, 83, 277-279.

130. Pinkerton, F.E.; Meyer, M.S.; Meisner, G.P.; Balogh, M.P. Improved Hydrogen Release from $\mathrm{LiB}_{0.33} \mathrm{~N}_{0.67} \mathrm{H}_{2.67}$ with Novel Metal Additives. J. Phys. Chem. B 2006, 110, 7967-7974.

131. Chater, P.A.; David, W.I.F.; Johnson, S.R.; Edwards, P.P.; Anderson, P.A. Synthesis and Crystal Structure of $\mathrm{Li}_{4} \mathrm{BH}_{4}\left(\mathrm{NH}_{2}\right)_{3}$. Chem. Commun. 2006, 23, 2439-2441.

132. Noritake, T.; Aoki, M.; Towata, S.; Ninomiya, A.; Nakamori, Y.; Orimo, S. Crystal Structure Analysis of Novel Complex Hydrides Formed by the Combination of $\mathrm{LiBH}_{4}$ and $\mathrm{LiNH}_{2}$. Appl. Phys. A 2006, 83, 277-279.

133. Alapati, S.V.; Johnson, J.K.; Sholl, D.S. Stability Analysis of Doped Materials for Reversible Hydrogen Storage in Destabilized Metal Hydrides. Phys. Rev. B 2007, 76, 104108.

134. Yang, J.; Sudik, A.; Wolverton, C. Destabilizing $\mathrm{LiBH}_{4}$ with a Metal (M $=\mathrm{Mg}, \mathrm{Al}, \mathrm{Ti}, \mathrm{V}, \mathrm{Cr}$, or $\mathrm{Sc})$ or Metal Hydride $\left(\mathrm{MH}_{2}=\mathrm{MgH}_{2}, \mathrm{TiH}_{2}, \mathrm{CaH}_{2}\right)$. J. Phys. Chem. 2007, 111, 19134-19140.

135. Siegel, D.J.; Wolverton, C.; Ozoliņš, V. Thermodynamics Guidelines for the Prediction of Hydrogen Storage Reactions and Their Application to Destabilized Hydride Mixtures. Phys. Rev. B 2007, 76, 134102.

136. Bösenberg, U.; Doppiu, S.; Mosegaard, L.; Barkhordarian, G.; Eigen, N.; Borgschulte, A.; Jensen, T.R.; Cerenius, Y.; Gutfleisch, O.; Klassen, T.; Dornheim, M.; Bormann, R. Hydrogen Sorption Properties of $\mathrm{MgH}_{2}-\mathrm{LiBH}_{4}$ Composites. Acta Mater. 2007, 55, 3951-3958. 
137. Kang, X.-D.; Wang, P.; Ma, L.-P.; Cheng, H.-M. Reversible Hydrogen Storage in $\mathrm{LiBH}_{4}$ Destabilized by Milling with Al. Appl. Phys. A 2007, 89, 963-966.

138. Pinkerton, F.E.; Meyer, M.S. Reversible Hydrogen Storage in the Lithium BorohydrideCalcium Hydride Coupled System. J. Alloys Compd. 2008, 464, L1-L4.

139. Wolverton, C.; Siegel, D.J.; Akbarzadeh, A.R.; Ozoliņš, V. Discovery of Novel Hydrogen Storage Materials: An Atomci Scale Computional Approach. J. Phys.: Condens. Matter 2008, 20, 064228.

140. Sudik, A.; Yang, J.; Halliday, D.; Wolverton, C. Hydrogen Storage Properties in $\left(\mathrm{LiNH}_{2}\right)_{2}-\mathrm{LiBH}_{4}-\left(\mathrm{MgH}_{2}\right)_{X}$ Mixture $(x=0.0-1.0)$. J. Phys. Chem. C 2008, 112, 4384-4390.

141. Yang, J.; Sudik, A.; Siegel, D.J.; Halliday, D.; Drews, A.; Carter, R.O., III; Wolverton, C.; Lewis, G.J.; Sachtler, J.W.A.; Low, J.J.; Faheem, S.A.; Lesch, D.A.; Ozoliņš, V. A SelfCatalyzing Hydrogen-Storage Material. Angew. Chem. Int. Ed. 2008, 47, 882-887.

142. Alapati, S.V.; Johnson, J.K.; Sholl, D.S. Large-Scale Screening of Metal Hydride Mixtures for High-Capacity Hydrogen Storage from First-Principle Calculations. J. Phys. Chem. C 2008, 112, 5258-5262.

143. Purewal, J.; Hwang, S.-J.; Bowman, R.C., Jr.; Rönnebro, E.; Fultz, B.; Ahn, C. Hydrogen Sorption Behavior of the $\mathrm{ScH}_{2}-\mathrm{LiBH}_{4}$ System: Experimental Assesment of Chemical Destabilization Effects. J. Phys. Chem. C 2008, 112, 8481-8485.

144. Jin, S.-A.; Lee, Y.-S.; Shim, J.-H.; Cho, Y.W. Reversible Hydrogen Storage in $\mathrm{LiBH}_{4}-\mathrm{MgH}_{2}$ $(\mathrm{M}=\mathrm{Ce}, \mathrm{Ca})$. J. Phys. Chem. C 2008, 112, 9520-9524.

145. Wan, X.; Markmaitree, T.; Osborn, W.; Shaw, L.L. Nanoengineering-Enabled Solid-State Hydrogen Uptake and Release in the $\mathrm{LiBH}_{4}$ Plus $\mathrm{MgH}_{2}$ System. J. Phys. Chem. C 2008, 112, 18232-18243.

146. Langmi, H.W.; McGrady, G.S. Ternary Nitrides for Hydrogen Storage: Li-B-N, Li-Al-N and Li-Ga-N Systems. J. Alloys Compd. 2008, 466, 287-292.

147. Jin, S.-A.; Shim, J.-H.; Cho, Y.W.; Yi, K.-W.; Zabara, O.; Fichtner, M. Reversible Hydrogen Storage in $\mathrm{LiBH}_{4}$-Al-LiH Composite Powder. Scripta Mater. 2008, 58, 963-965.

148. Fan, M.-Q.; Sun, L.-X.; Zhang, Y.; Xu, F.; Zhang, J.; Chu, H.-L. The Catalytic Effect of Additive $\mathrm{Nb}_{2} \mathrm{O}_{5}$ on the Reversible Hydrogen Storage Performances of $\mathrm{LiBH}_{4}-\mathrm{MgH}_{2}$ Composite. Int. J. Hydrogen Energy. 2008, 33, 74-80.

149. Tang, W.S.; Wu, G.T.; Liu, T.; Wee, A.T.S.; Yong, C.K.; Xiong, Z.; Hor, T.S.; Chen, P. Cobalt-Catalyzed Hydrogen Desorption from the $\mathrm{LiNH}_{2}-\mathrm{LiBH}_{4}$ System. Dalton Trans. 2008, 18, 2395-2399.

150. Bösenberg, U.; Vainio, U.; Pranzas, P.K.; Bellosta von Colbe, J.M.; Goerigk, G.; Welter, E.; Dornheim, M.; Schreyer, A.; Bormann, R. On the Chemical State and Distribution of Zr- and V-Based Additives in Reactive Hydride Composites. Nanotechnology 2009, 20, 204003.

151. Wang, P.J.; Ma, L.P.; Fang, Z.Z.; Kang, X.D.; Wang, P. Improved Hydrogen Storage Properties of Li-Mg-B-H System by Milling with Titanium Trifluoride. Energy Environ. Sci. 2009, 2, $120-123$.

152. Du, A.J.; Smith, S.C.; Yao, X.D.; Sun, C.H.; Li, L. Lu, G.Q. First Principle Study of Hydrogen of $\mathrm{MgB}_{2}$ : An Important Step toward Reversible Hydrogen Storage in the Coupled $\mathrm{LiBH}_{4} / \mathrm{MgH}_{2}$ System. J. Nanosci. Nanotechnol. 2009, 9, 4388-4391. 
153. Yang, J.; Hirano, S. Improving the Hydrogen Reaction Kinetics of Complex Hydrides. Adv. Mater. 2009, 21, 1-6.

154. Graetz, J.; Chaudhuri, S.; Salguero, T.T.; Vajo, J.J.; Meyer, M.S.; Pinkerton, F.E. Local bonding and atomic environments in Ni-catalyzed complex hydrides. Nanotechnology 2009, 20, 204007.

155. Sudik, A.; Yang, J.; Siegel, D.J.; Wolverton, C.; Carter, R.O., III; Drews, A.R. Impact of Stoichiometry on the Hydrogen Storage Properties of $\mathrm{LiNH}_{2}-\mathrm{LiBH}_{4}-\mathrm{MgH}_{2}$ Ternary Composites. J. Phys. Chem. C 2009, 113, 2004-2013.

156. Walker, G.S.; Grant, D.M.; Price, T.C.; Yu, X.B.; Legrand, V. High Capacity Multicomponent Hydrogen Storage Materials: Investigation of the Effect of Stoichimetry and Decomposition Conditions on the Cycling Behaviour of $\mathrm{LiBH}_{4}-\mathrm{MgH}_{2}$. J. Power Sources 2009, 194, 1128-1134.

157. Mao, J.F.; Guo, Z.P.; Liu, H.K.; Yu, X.B. Reversible Hydrogen Storage in Titanium-Catalyzed $\mathrm{LiAlH}_{4}-\mathrm{LiBH}_{4}$. J. Alloys. Compd. 2009, 487, 434-438.

158. Puszkiel, J.A.; Gennari, F.C. Reversible Hydrogen Storage in Metal-Doped Mg-LiBH Composites. Scripta Mater. 2009, 60, 667-670.

159. Zhang, Y.; Tian, Q.; Chu, H.L.; Zhang, J.; Sun, L.; Sun, J.; Wen, Z. Hydogen De/Resorption Properties of the $\mathrm{LiBH}_{4}-\mathrm{MgH}_{2}-\mathrm{Al}$ System. J. Phys. Chem. C 2009, 113, 21964-21969.

160. Wu, H.; Zhou, MI.; Wang, K.; Udovic, T.J.; Rush, J.J.; Yildirim, T.; Bendersky, L.A.; Gross, A.F.; van Atta, S.L.; Vajo, J.J.; Pinkerton, F.E.; Meyer, M.S. Size Effects on the Hydrogen Storage Properties of Nanoscaffolded $\mathrm{Li}_{3} \mathrm{BN}_{2} \mathrm{H}_{8}$. Nanotechnology 2009, 20, 204002.

161. Pinkerton, F.E.; Meyer, M.S. Hydrogen Desorption Behavior of Nickel-Chloride-Catalyzed Stoichiometric $\mathrm{Li}_{4} \mathrm{BN}_{3} \mathrm{H}_{10}$. J. Phys. Chem. C 2009, 113, 11172-11176.

162. Kim, J.W. Friedrichs, O.; Ahn, J.-P. Kim, D.H.; Kim, S.C.; Remhof, A.; Chung, H.-S.; Lee, J.; Shim, J.-H.; Cho, Y.W.; Züttel, A.; Oh, K.H. Microstructural Change of $2 \mathrm{LiBH}_{4} / \mathrm{Al}$ with Hydrogen Sorption cycling: Separation of Al and B. Scripta Mater. 2009, 60, 1089-1092.

163. Friedrichs, O.; Kim, J.W.; Remhof, A.; Buchter, F.; Borgschulte, A.; Wallacher, D.; Cho, Y.W.; Fichtner, M.; Oh, K.H.; Züttel, A. The Effect of Al on the Hydrogen Sorption Mechanism of $\mathrm{LiBH}_{4}$. Phys. Chem. Chem. Phys. 2009, 11, 1515-1520.

164. Blanchard, D.; Shi, Q.; Boothroyd, C.B.; Vegge, T. Reversibility of Al/Ti Modified $\mathrm{LiBH}_{4}$. J. Phys. Chem. C 2009, 113, 14059-14066.

165. Zhang, Y.; Tian, Q.; Zhang, J.; Liu, S.-S.; Sun, L.-X. The Dehydrogenation Reactions and Kinetics of $2 \mathrm{LiBH}_{4}-\mathrm{Al}$ Composite. J. Phys. Chem. C 2009, 113, 18424-18430.

166. Singer, J.P.; Meyer, M.S.; Speer, R.M., Jr.; Fischer, J.E.; Pinkerton, F.E. Determination o the Phase Behavior of $\left(\mathrm{LiNH}_{2}\right)_{\mathrm{c}}\left(\mathrm{LiBH}_{4}\right)_{1-\mathrm{c}}$ Quaternary Hydride through in Situ X-ray Diffraction. J. Phys. Chem. C 2009, 113, 18927-18934.

167. Li, W.; Vajo, J.J.; Cumberland, R.W.; Liu, P.; Hwang, S.-J.; Kim, C.; Bowman, R.C., Jr. Hydrogenation of Magnesium Nickel Boride for Reversible Hydrogen Storage. Phys. Chem. Lett. 2010, 1, 69-72.

168. Wang, P.-J.; Fang, Z.-Z.; Ma, L.-P.; Kang, X.-D.; Wang, P. Effect of Carbon Addition on Hydrogen Storage Behaviors of Li-Mg-B-H System. Int. J. Hydrogen Energy 2010, 35, 3072-3075. 
169. Shim, J.-H.; Lim, J.-H.; Rather, S.-U.; Lee, Y.-S.; Reed, D.; Kim, Y.; Book, D.; Cho, Y.W. Effect of Hydrogen Back Pressure on Dehydrogenation Behavior of $\mathrm{LiBH}_{4}$-Based Reactive Hydride Composites. Phys. Chem. Lett. 2010, 1, 59-63.

170. Deprez, E.; Muñoz-Márquez, M.A.; Roldán, M.A.; Prestipino, C.; Javier Palomares, F.; Bonatto Minella, C.; Bösenberg, U.; Dornheim, M.; Bormann, R.; Fernández, A.; Oxidation State and Local Structure of Ti-Based Additives in the Reactive Hydride Composite $2 \mathrm{LiBH}_{4}+\mathrm{MgH}_{2}$. J. Phys. Chem. 2010, 114, 3309-3317.

171. Bösenberg, U.; Kim, J.W.; Gosslar, D.; Eigen, N.; Jensen, T.G.; Bellosta von Colbe, J.M.; Zhou, Y.; Dahms, M.; Kim, D.H.; Günther, R.; Cho, Y.W.; Oh, K.H.; Klassen, T.; Bormann, R.; Dornheim, M. Role of Additives in $\mathrm{LiBH}_{4}-\mathrm{MgH}_{2}$ Reactive Hydride Composites for Sorption Kinetics. Acta Mater. 2010, 58, 3381-3389.

172. Price, T.C.; Grant, D.M.; Legrand, V.; Walker, G.S. Enhanced Kinetics for the $\mathrm{LiBH}_{4}: \mathrm{MgH}_{2}$ Multi-Component Hydrogen Storage System-The Effects of Stoichiometry and Decomposition Environment on Cycling Behaviour. Int. J. Hydrogen Energy 2010, 35, 4154-4161.

173. Somer, M.; Acar, S.; Koz, C.; Kokal, I.; Höhn, P.; Cardoso-Gil, R.; Aydemir, U.; Akselrud, L. $\alpha-$ and $\beta-\mathrm{Na}_{2}\left[\mathrm{BH}_{4}\right]\left[\mathrm{NH}_{2}\right]$ : Two Modifications of a Complex Hydride in the System $\mathrm{NaNH}_{2}-\mathrm{NaBH}_{4}$; Syntheses, Crystal Structures, Thermal Analyses, Mass and Vibrational Spectra. J. Alloys Compd. 2010, 491, 98-105.

174. Yu, X.B.; Guo, Y.H.; Sun, D.L.; Yang, Z.X.; Ranjbar, A.; Guo, Z.P.; Liu, H.K.; Dou, S.X. A Combined Hydrogen Storage System of $\mathrm{Mg}\left(\mathrm{BH}_{4}\right)_{2}-\mathrm{LiNH}_{2}$ with Favorable Dehydrogenation. J. Phys. Chem. C 2010, 114, 4733-4737.

175. Mao, J.; Guo, Z.; Leng, H.; Wu, Z.; Guo, Y.; Yu, X.; Liu, H. Reversible Hydrogen Storage in Destabilized $\mathrm{LiAlH}_{4}-\mathrm{MgH}_{2}-\mathrm{LiBH}_{4}$ Ternary-Hydride System Doped with $\mathrm{TiF}_{3}$. J. Phys. Chem. C 2010, 114, 11643-11649.

176. Ravnsbæk, D.B.; Jensen, T.R. Tuning hydrogen storage properties and reactivity: Investigation of the $\mathrm{LiBH}_{4}-\mathrm{NaAlH}_{4}$ sytem. J. Phys Chem. Sol. 2010, 71, 1144-1149.

177. Mauron, P.; Bielmann, M.; Remhof, A.; Züttel, A.; Shim, J.-K.; Cho, Y.W. Stability of the $\mathrm{LiBH}_{4} / \mathrm{CeH}_{2}$ Composite System Determined by Dynamic pcT Measurements. J. Phys. Chem. C 2010, 114, 16801-16805.

178. Bösenberg, U.; Ravnsbæk, D.B.; Hagemann, H.; D’Anna, V.; Minella, C.B.; Pistidda, C.; van Beek, W.; Jensen, T.R.; Bormann, R.; Dornheim, M. Pressure and Temperature Influence on the Desorption Pathway of the $\mathrm{LiBH}_{4}-\mathrm{MgH}_{2}$ Composite System. J. Phys. Chem. C 2010, 114, $15212-15217$.

179. Zeng, L.; Miyaoka, H.; Ichikawa, T.; Kojima, Y. Superior Hydrogen Exchange Effect in the $\mathrm{MgH}_{2}-\mathrm{LiBH}_{4}$ System. J. Phys. Chem. C 2010, 114, 13132-13135.

180. Crosby, K.; Shaw, L.L. Dehydriding and re-hydriding properties of high-energy ball milled $\mathrm{LiBH}_{4}+\mathrm{MgH}_{2}$ mixture. Int. J. Hydrogen Energy 2010, 35, 7519-7529.

181. Choudhury, P.; Bhethanabotla, V.R.; Stefanakos, E. First principles study to identify the reversible reaction step of a multinary hydrogen storage "Li-Mg-B-N-H" system. Int. J. Hydrogen Energy 2010, 35, 9002-9011.

182. Shaw, L.L.; Wan, X.; Hu, J.Z.; Kwak, J.H.; Yang, Z. Solid-State Hydriding Mechanism in the $\mathrm{LiBH}_{4}-\mathrm{MgH}_{2}$ System. J. Phys. Chem. C 2010, 114, 8089-8098. 
183. Garroni, S.; Milanese, C.; Girella, A.; Marini, A.; Mulas, G.; Menéndez, E.; Pistidda, C.; Dornheim, M.; Suriñach, S.; Baró, M.D. Sorption Properties of $\mathrm{NaBH}_{4} / \mathrm{MH}_{2}(\mathrm{M}=\mathrm{Mg}$, Ti) Powder System. Int. J. Hydrogen. Energy 2010, 35, 5434-5441.

184. Gennari, F.C.; Puszkiel, J.A. Enhanced Hydrogen Sorption Kinetics of $\mathrm{Mg}_{50} \mathrm{Ni}_{-} \mathrm{LiBH}_{4}$. J. Power Sources. 2010, 195, 3266-3274.

185. Hattrick-Simpers, J.R.; Maslar, J.E.; Niemann, M.U.; Chium, C.; Srinivasan, S.S.; Stefanakos, E.K.; Bendersky, L.A. Raman Spectroscopic Observation of Dehydrogenation in Ball-Milled $\mathrm{LiNH}_{2}-\mathrm{LiBH}_{4}-\mathrm{MgH}_{2}$ Nanoparticles. Int. J. Hydrogen Energy. 2010, 35, 6323-6331.

186. Barkhordarian, G.; Klassen, T.; Dornheim, M.; Bormann, R. Unexpected Kinetic Effect of $\mathrm{MgB}_{2}$ in Reactive Composites Containing Complex borohydrides. J. Alloys Compd. 2007, 440, L18-L21.

187. Barkhordarian, G.; Jensen, T.R.; Doppiu, S.; Bo1senberg, U.; Borgschulte, A.; Gremaud, R.; Cerenius, Y.; Dornheim, M.; Klassen, T.; Bormann, R. Formation of $\mathrm{Ca}\left(\mathrm{BH}_{4}\right)_{2}$ from Hydrogenation of $\mathrm{CaH}_{2}+\mathrm{MgB}_{2}$ Composite. J. Phys. Chem. C 2008, 112, 2743-2749.

188. Hu, J.Z.; Kwak, J.H.; Y, Z.; Wan, X.; Shaw, L.L. Direct Observation of Ion Exchange in Mechanically Activated $\mathrm{LiH}+\mathrm{MgB}_{2}$ System Using Ultrahigh Field Nuclear Magnetic Resonance Spectroscopy. Appl. Phys. Lett. 2009, 94, 141905.

189. Gosalawit-Utke, R.; Bellosta von Colbe, J.M.; Dornheim, M.; Jensen, T.R.; Cerenius, Y.; Minella, C.B.; Peschke, M.; Bormann, R. LiF-MgB 2 System for Reversible Hydrogen Storage. J. Phys. Chem. C 2010, 114, 10291-10296.

190. Gonzalez-Silveira, M.; Gremaud, R.; Schreuders, H.; van Setten M.J.; Batyrev, E.; Rougier, A.; Dupont, L.; Bardají, E.G.; Lohstroh, W.; Dam, B. In-Situ Deposition of Alkali and Alkaline Earth Hydride Thin Films To Investigate the Formation of Reactive Hydride Composites. J. Phys. Chem. C 2010, 114, 13895-13901.

191. Rongeat, C.; D’Anna, V.; Hagemann, H.; Borgschulte, A.; Züttel, A.; Schultz, L.; Gutfleisch, O. Effect of Additives on the Synthesis and Reversibility of $\mathrm{Ca}\left(\mathrm{BH}_{4}\right)_{2}$. J. Alloys Compd. 2010, 493, 281-287.

192. Kim, Y.; Reed, D.; Lee, Y.-S.; Shim, J.-H.; Han, H.N.; Book, D.; Cho, Y.W. Hydrogenation Reaction of $\mathrm{CaH}_{2}-\mathrm{CaB}_{6}-\mathrm{Mg}$ Mixture. J. Alloys Compd. 2010, 492, 597-600.

193. Bogdanović, B.; Schwickardi, M. Ti-doped alkali metal aluminium hydrides as potential novel reversible hydrogen storage materials. J. Alloy. Compd. 1997, 253-254, 1-9.

194. Au, M.; Jurgensen, A. Modified Lithium Borohydrides for Reversible Hydrogen Storage. J. Phys. Chem. B 2006, 110, 7062-7067.

195. Au, M.; Jurgensen, A.; Zeigler, K. Modified Lithium Borohydrides for Reversible Hydrogen Storage (2). J. Phys. Chem. B 2006, 110, 26482-26487.

196. Yu, X.B.; Wu, Z.; Chen, Q.R.; Li, Z.L.; Weng, B.C.; Huang, T.S. Improved Hydrogen Storage Properties of $\mathrm{LiBH}_{4}$ Destabilized by Carbon. Appl. Phys. Lett. 2007, 90, 034106.

197. Zhang, Y.; Zhang, W.-S.; Wang, A.-Q.; Sun, L.-X.; Fan, M.-Q.; Chu, H.-L. Sun, J-C.; Zhang, T. $\mathrm{LiBH}_{4}$ Nanoparticles Supported by Disordered Mesoporous Carbon: Hydrogen Storage Performances and Destabilization Mechanisms. Int. J. Hydrogen Energy. 2007, 32, 3976-3980. 
198. Varin, R.A.; Chiu, C.; Wronski, Z.S.; Calka, A. The Effects of Oxidized and Oxide-Free Boron on the Mg-B-H Nanohydrides Transformation in the Nearly Nanosized Powders. Solid State Phenom. 2007, 128, 47-52.

199. Mosegaard, L.; Møller, B.; Jørgensen, J.-E.; Filinchuk, Y.; Cerenius, Y.; Hanson, J.; Dimasi, E.; Besenbacher, F.; Jensen, T.R. Reactivity of $\mathrm{LiBH}_{4}$ : In Situ Synchrotron Radian Powder X-ray Diffraction Study. J. Phys. Chem. C 2008, 112, 1299-1303.

200. Yin, L.; Wang, P.; Fang, Z.Z.; Cheng, H. Thermodynamically Tuning $\mathrm{LiBH}_{4}$ by Fluorine Anion Doping for Hydrogen Storage: A Density functional Study. Chem. Phys. Lett. 2008, 450, 318-321.

201. Zhang, Y.; Zhang, W.-S.; Fan, M.-Q.; Liu, S.-S.; Chu, H.-L.; Zhang, Y.-H.; Gao, X-Y.; Sun, L.-X. Enhanced Hydrogen Storage Performance of $\mathrm{LiBH}_{4}-\mathrm{SiO}_{2}-\mathrm{TiF}_{3}$ Composite. J. Phys. Chem. C 2008, 112, 4005-4110.

202. Fang, Z.Z.; Kang, X.D.; Dai, H.B.; Zhang, M.J.; Wang, P.; Cheng, H.M. Reversible Dehydrogenation of $\mathrm{LiBH}_{4}$ Catalyzed by As-Prepared Sing-Walled Carbon Nanotubes. Scripta Mater. 2008, 58, 922-925.

203. Xu, J.; Yu, X.B.; Zou, Z.Q.; Li, Z.L.; Wu, Z.; Akins, L.D.; Yang, H. Enhanced Dehydrogenation of $\mathrm{LiBH}_{4}$ Catalyzed by Carbon-Supported Pt Nanoparticles. Chem. Commun. 2008, 44, $5740-5742$.

204. Fang, Z.-Z.; Kang, X.-D.; Wang, P.; Cheng, H.-M. Improved Reversible Dehydrogenation of Lithium Borohydride by Milling with As-Prepared Single-Walled Carbon Nanotubes. J. Phys. Chem. C 2008, 112, 17023-17029.

205. Au, M.; Jurgensen, A.R.; Spencer, W.A.; Anto, D.A.; Pinkerton, F.E.; Hwang, S.-J.; Kim, C.; Bowman, R.C., Jr. Stability and Reversibility of Lithium Borohydrides Doped by Metal Halides and Hydrides. J. Phys. Chem. C 2008, 112, 18661-18671.

206. Yu, X.B.; Grant, D.M.; Walker, G.S. Dehydrogenation of $\mathrm{LiBH}_{4}$ Destabilized with Various Oxides. J. Phys. Chem. C 2009, 113, 17945-17949.

207. Arnbjerg, L.M.; Ravnsbæk, D.B.; Filinchuk, Y.; Vang, R.T.; Cerenius, Y.; Besenbacher, F.; Jørgensen, J.-E.; Jakobsen, H.J.; Jensen, T.R. Structure and Dynamics for $\mathrm{LiBH}_{4}-\mathrm{LiCl}$ Solid Solutions. Chem. Mater. 2009, 21, 5772-5782.

208. Guo, Y.H.; Yu, X.B.; Gao, L.; Xia, G.L.; Guo, Z.P.; Liu, H.K. Significantly Improved Dehydrogenation of $\mathrm{LiBH}_{4}$ Destabilized by $\mathrm{TiF}_{3}$. Energy Environ. Sci. 2010, 3, 465-470.

209. Fang, Z.Z.; Kang, X.D.; Wang, P. Improved Hydrogen Storage Properties of $\mathrm{LiBH}_{4}$ by Mechanical Milling with Various Carbon Additives. J. Int. Hydrogen Energy 2010, 35, 8247-8252.

210. Zhang, B.J.; Liu, B.H. Hydrogen Desorption from $\mathrm{LiBH}_{4}$ destabilized by chlorides of transition metal Fe, Co, and Ni. Int. J. Hydrogen Energy 2010, 35, 7288-7294.

211. Gutowska, A.; Li, L.; Shin, Y.; Wang, C.M.; Li, X.S.; Linehan, J.C.; Smith, R.S.; Kay, B.D.; Schmid, B.; Shaw, W.; Gutowski, M.; Autrey, T. Nanoscaffold Mediates Hydrogen Release and the Reactivity of Ammonia Borane. Angew. Chem. Int. Ed. 2005, 44, 3578.

212. Gross, A.F.; Vajo, J.J.; van Atta, S. L.; Olson, G.L. Enhanced Hydrogen Storage Kinetics of $\mathrm{LiBH}_{4}$ in Nanoporous Carbon Scaffolds. J. Phys. Chem. C 2008, 112, 5651-5657. 
213. Fang, Z.Z.; Wang, P.; Rufford, T.E.; Kang, X.D.; Lu, G.Q.; Cheng, H.M. Kinetic- and Thermodynamic-Based Improvements of Lithium Borohydride Incorporated Into Activated Carbon. Acta Mater. 2008, 56, 6257-6263.

214. Cahen, S.; Eymery, J.-B.; Janot, R.; Tarascon, J.-M. Improvement of the $\mathrm{LiBH}_{4} \mathrm{Hydrogen}$ Desorption by Inclusion into Mesoporous Carbons. J. Power Sources 2009, 189, 902-908.

215. Ingleson, M.J.; Barrio, J.P.; Bacsa, J.; Steiner, A.; Darling, G.R.; Jones, J.T.A.; Khimyak, Y.Z.; Rosseinsky, M.J. Magnesium Borohydride Confined in a Metal-Organic Framework: A Preorganized System for Facile Arene Hydroboration. Angew. Chem. Int. Ed. 2009, 48, 2012-2016.

216. Fichtner, M.; Zhao-Karger, Z.; Hu, J.; Roth, A.; Weidler, P. The Kinetic Properties of $\operatorname{Mg}\left(\mathrm{BH}_{4}\right)_{2}$ Infiltrated in Activated Carbon. Nanotechnology 2009, 20, 204029.

217. Ngene, P.; Adelhelm, P.; Beale, A.M.; de Jong, K.P.; de Jongh, P.E. LiBH $4 / \mathrm{SBA}_{-15}$ Nanocomposites Prepared by Melt infiltration under Hydrogen pressure: Synthesis and Hydrogen Sorption Properties. J. Phys. Chem. C 2010, 114, 6163-6168.

218. Shane, D.T.; Corey, R.L.; McIntosh, C.; Rayhel, L.H.; Bowman, R.C., Jr.; Vajo, J.J.; Gross, A.F.; Conradi, M.S. $\mathrm{LiBH}_{4}$ in Carbon Aerogel Nanoscaffolds: An NMR Study of Atomic Motions. J. Phys. Chem. C 2010, 114, 4008-4014.

219. Liu, X.; Peaslee, D.; Jost, C.Z.; Majzoub, E.H. Controlling the Decomposition Pathway of $\mathrm{LiBH}_{4}$ via Confinement in Highly Ordered Nanoporous Carbon. J. Phys. Chem. C 2010, 114, 14036-14041.

220. Ngene, P.; van Zwienen, M.R.; de Jongh, P.E. Reversibility of the hydrogen desorption from $\mathrm{LiBH}_{4}$ : A synergetic effect of nanoconfinement and $\mathrm{Ni}$ addition. Chem. Comm. 2010, 46, 8201-5203.

221. Nielsen, T.K.; Bösenber, U.; Gosalawit, R.; Dornheim, M.; Cerenius, Y.; Besenbacher, F.; Jensen, T.R. A Reversible Nanoconfined Chemical Reaction. ACS NANO 2010, 4, 3903-3908.

222. Sartori, S.; Knudsen, K.D.; Zhao-karger, Z.; Bardaji, E.G.; Muller, J.; Fichtner, M.; Hauback, B.C. Sartori, S.; Knudsen, K.D.; Zhao-karger, Z.; Bardaji, E.G.; Muller, J.; Fichtner, M.; Hauback, B.C. Nanoconfined Magnesium Borohydride for Hydrogen Storage Application Investigation by SANS and SAXS. J. Phys. Chem. C 2010, 114, 18785-18789.

(C) 2011 by the authors; licensee MDPI, Basel, Switzerland. This article is an open access article distributed under the terms and conditions of the Creative Commons Attribution license (http://creativecommons.org/licenses/by/3.0/). 